\title{
The Global Value of Coal
}


The International Energy Agency (IEA), an autonomous agency, was established in November 1974. Its primary mandate was - and is - two-fold: to promote energy security amongst its member countries through collective response to physical disruptions in oil supply, and provide authoritative research and analysis on ways to ensure reliable, affordable and clean energy for its 28 member countries and beyond. The IEA carries out a comprehensive programme of energy co-operation among its member countries, each of which is obliged to hold oil stocks equivalent to 90 days of its net imports. The Agency's aims include the following objectives:

- Secure member countries' access to reliable and ample supplies of all forms of energy; in particular, through maintaining effective emergency response capabilities in case of oil supply disruptions.

- Promote sustainable energy policies that spur economic growth and environmental protection in a global context - particularly in terms of reducing greenhouse-gas emissions that contribute to climate change.

- Improve transparency of international markets through collection and analysis of energy data.

- Support global collaboration on energy technology to secure future energy supplies and mitigate their environmental impact, including through improved energy

efficiency and development and deployment of low-carbon technologies.

- Find solutions to global energy challenges through engagement and dialogue with non-member countries, industry, international organisations and other stakeholders.

IEA member countries:

(C) OECD/IEA, 2012

\section{International Energy Agency}

9 rue de la Fédération 75739 Paris Cedex 15, France

www.iea.org

\section{Spain}

Sweden

\section{Switzerland}

Turkey

\section{United Kingdom}

United States 


\section{Acknowledgements}

This paper has been prepared by the IEA Coal Industry Advisory Board (CIAB). The main author is Dr. Frank Clemente from Penn State University, USA, and we are especially grateful to Peabody Energy for sponsoring him in this task. Our gratitude also goes to CIAB Members and Associates, and the World Coal Association and its members, for their support, encouragement, guidance, information and comments provided during the preparation of the paper.

While it is not practical to list all the individuals who have contributed, we must mention in particular the contributions made by Mr. Frederick Palmer from Peabody Energy, Dr. John Groom from Anglo American and Mr. Alex Zapantis from Rio Tinto Energy in structuring and guiding the work.

Special thanks are extended to staff at the IEA, including Carlos Fernández Alvarez for his facilitation of the publishing of this paper, to Marilyn Smith and Janet Pape for editing, and to Angela Gosmann and Bertrand Sadin for the design.

\section{I A B}

\section{Coal Industry Advisory Board}

The IEA Coal Industry Advisory Board (CIAB) is a group of high-level executives from coal-related industrial enterprises, established by the IEA in July 1979 to provide advice to the IEA Executive Director on a wide range of issues relating to coal. The CIAB currently has 46 members from 21 countries, contributing valuable experience in the fields of coal production, trading and transportation, electricity generation and other aspects of coal use.

For more information about the IEA Coal Industry Advisory Board, please refer to www.iea.org/ciab, or contact Carlos Fernández Alvarez at the IEA (carlos.fernandez@iea.org) or Brian Heath, CIAB Executive Co-ordinator (mail@ciab.org.uk). 


\section{Foreword}

Coal plays an essential role in our global energy mix, particularly for power generation; and through that to the alleviation of energy poverty. The use of coal continues to grow rapidly and

Page $\mid 2$ will continue, together with other fuels, to support world economic and social development particularly in rapidly developing world economies such as China and India. The purpose of this paper is to highlight for policy makers the value of coal to world economic and social development and so encourage development of a policy environment that will allow the coal and electricity industries to make the necessary investments in production capacity and $\mathrm{CO}_{2}$ emissions reduction technologies. 


\section{Table of Contents}

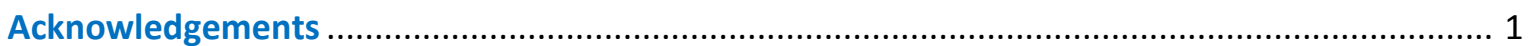

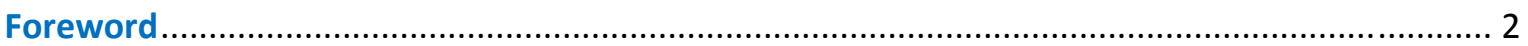

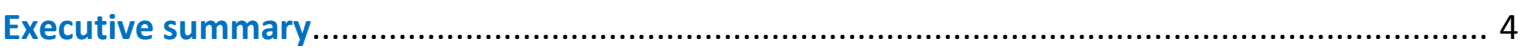

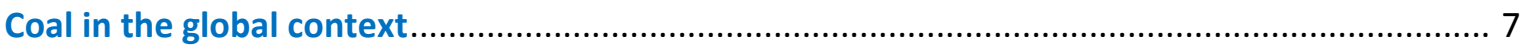

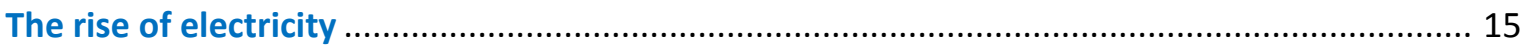

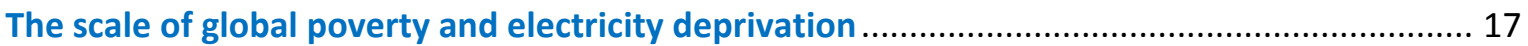

Coal-driven progress in China serves as a model for development............................................ 19

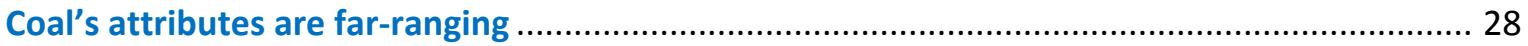

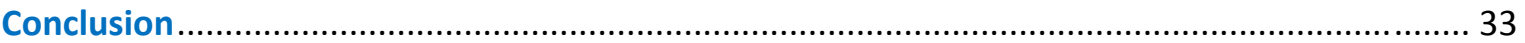

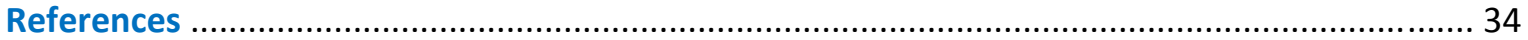

\section{List of Figures}

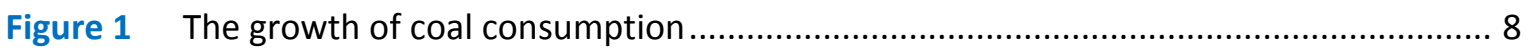

Figure 2 The global scope of poverty and electricity deprivation relative to the size

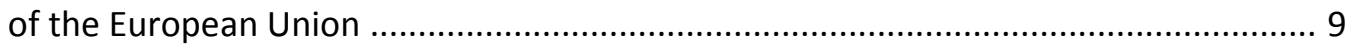

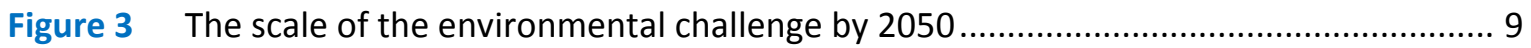

Figure 4 World per-capita energy use and gross domestic product, 1991-2008 ….................... 10

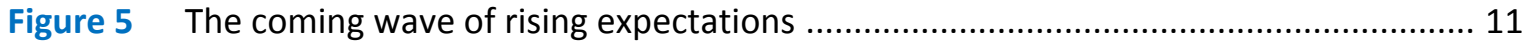

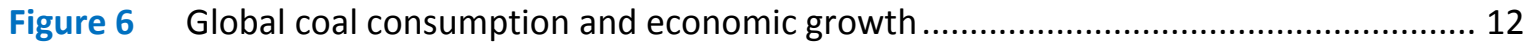

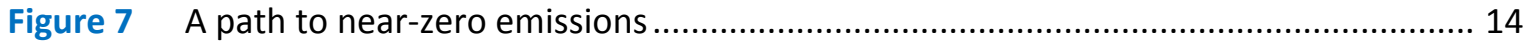

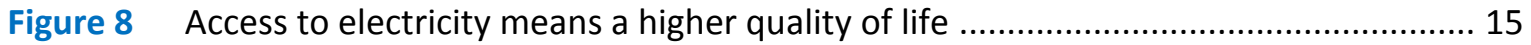

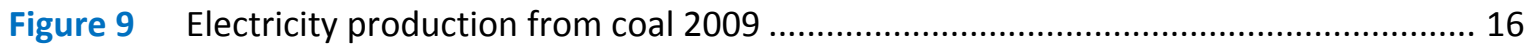

Figure 10 Historical and projected global electricity generation ............................................... 16

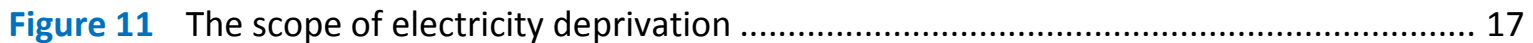

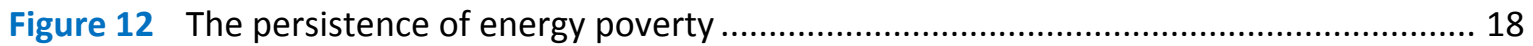

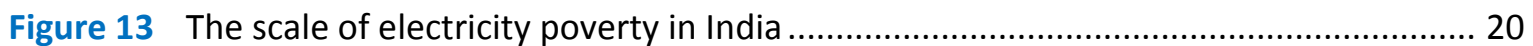

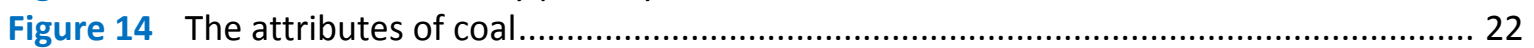

Figure 15 Clean coal technologies have reduced regulated emissions in the United States ....... 23

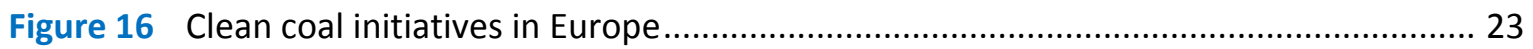

Figure 17 Characteristics of large-scale integrated CCS projects .............................................. 25

Figure 18 Levelised cost of electricity (LCOE) in China, an example of a developing country ..... 29

Figure 19 China's plan of converting coal in Xinjiang Province by 2020 ..................................... 30

Figure 20 The rise of the Chinese metropolis: the steel required to build cities alone ............... 31

\section{List of Tables}

Table 1 Projected incremental sources of electricity through 2035 ........................................ 13

Table 2 IEA scenarios of global electricity production by energy source .................................. 13

Table 3 Proven recoverable coal reserves across geographic and political regions................... 28

Table 4 Economic benefits from operation and maintenance of $360 \mathrm{GW}$ of advanced coal-based generation facilities with CCS. 


\section{Executive summary}

The Copenhagen Accord (2009) identified two crucial challenges at the global level: first, the need for the nations of the world to meet the growing challenge of climate change and "cooperate in achieving the peaking of global and national emissions as soon as possible"; and second, the need

Page | 4 to "bear in mind that social and economic development and poverty eradication are the first and overriding priorities of developing countries."

The objective of the current document is to delineate the past, current and potential contributions of coal in meeting both challenges. The discussion focuses on the global value of coal and the opportunities clean coal technologies present to continue and expand utilisation of this vast energy resource, thereby allowing coal to continue to play a significant role in the world's socio-economic and environmental goals. Climate objectives and the eradication of poverty are complementary, not conflicting, goals. They are compatible and represent an achievable future for all societies.

The challenges are real and substantial. Over 1.4 billion people are totally without electricity and at least another two billion have highly constrained access to power. At the same time, calls to reduce emissions by $80 \%$ by 2050 face the powerful headwind of rising energy demand due to economic growth, increases in population and an ever greater proportion of people living in cities. The world needs much more energy, particularly electricity, yet at the same time must significantly reduce greenhouse-gas (GHG) emissions, including those of carbon dioxide $\left(\mathrm{CO}_{2}\right)$. This report is founded on the premise that increased coal-based generation efficiencies, coupled with carbon capture and storage (CCS), can help the world meet the goals of a significant reduction in $\mathrm{CO}_{2}$ emissions amid sustained economic growth, the eradication of poverty and elimination of energy deprivation. The Coal Industry Advisory Board (2009) stated the situation succinctly:

- The future use of increasing quantities of coal worldwide is inevitable if the world is to avoid a damaging energy crunch and support the development needs of poorer nations.

- The mitigation of $\mathrm{CO}_{2}$ emissions from current and higher future global energy use...will require the deployment of all forms of currently available response, including substantial investments in renewable energy and nuclear power.

- Improving the efficiency of both existing and future coal-fired power plants has the potential to generate significant and cost-effective emissions reduction, and must be a priority for all coal-using countries.

- Various studies have reinforced the importance of CCS as a cost-effective and critical component of climate change goals.

In addition, as the CIAB noted, in virtually every future scenario, coal will be an important part of the world's energy portfolio - especially in regard to electricity generation.

Electricity is the lifeblood of modern society and is essential to increases in quality of life, economic well-being and a clean environment. In societies with widespread access to electricity, people eat healthier, drink cleaner water, are more likely to survive childhood, live longer and are better educated. As the IEA (2010b) recently concluded, "the lack of access to modern energy services is a serious hindrance to economic and social development and must be overcome if the UN Millennium Development Goals (MDGs) are to be achieved." Women and girls are disproportionately affected by energy deprivation - upwards of $70 \%$ of people living in poverty are female (CARE, 2010).

Coal's foundational role in societal progress is well documented and reaches from the Industrial Revolution in the 1800 s to the rapid economic development of contemporary China. Indeed, as 
the IEA noted in 2009 (IEA, 2009f) "Coal has underpinned China's massive and unprecedented growth in output, fuelling an economic miracle that has helped to improve the standard of living." China's success with coal has not gone unnoticed as other developing countries aspire to a better life for their citizens. In India, for example, over 400 million people have no electricity. In fact, electricity poverty is a global blight; well over four billion people, at least $60 \%$ of the world's population, use fewer than 2350 kilowatt hours (kWh) per year, only one-third as much as a typical resident of the European Union.

But if coal has been a cornerstone of socio-economic progress, it has also been a matter of increasing concern over the potential impact on climate change through emission of $\mathrm{CO}_{2}$. In a carbon-constrained world, advancing clean coal technologies will be increasingly important, allowing the world to take advantage of immense reserves. In the area of electricity generation, for example, the two processes of (a) increased efficiency through supercritical and ultrasupercritical power plants and (b) CCS present a unique opportunity not only to move toward the eradication of poverty but also to meet the climate change goals delineated in the Copenhagen Accord.

Clean coal technologies have solved other emissions challenges. Since 1990, the US electric power industry has invested almost USD 100 billion to control emissions with marked success. The United States has made huge strides forward in reducing regulated emissions - particulate matter (PM), sulphur dioxide $\left(\mathrm{SO}_{2}\right)$, carbon monoxide $(\mathrm{CO})$, lead, ozone and nitrogen oxides (NOx) - while at the same time substantially increasing coal-based generation and meeting the electricity needs of an expanding population in a growing economy. Parallel progress has been made in a variety of nations, including Australia, Japan and Germany. Now the focus of the scientific and engineering community has turned to the management of $\mathrm{CO}_{2}$. The commercialisation and deployment of the next generation of clean coal technologies will propel continued environmental improvement and steady progress toward the final goal of near-zero emissions. Further, a portion of the captured $\mathrm{CO}_{2}$ will be utilised productively in such processes as enhanced oil recovery (EOR) and the manufacturing of cement and other products including food.

Coal is the cornerstone of global electricity, producing over 8200 terawatt hours (TWh) annually - about $41 \%$ of the world's power. Further, according to the 2011 New Policies Scenario of the IEA, coal generation will provide an additional 3800 TWh by 2035 - a $44 \%$ increase. In the Current Policies Scenario, coal would be required to deliver about 8700 new TWh - a $106 \%$ increase (IEA, 2011b). Alternatives required to replace this new coal generation could be overwhelming to the global economy. Consequently, in 2010, the IEA concluded that the high costs of alternative sources of electricity "demonstrate the importance of the availability of CCS as an option for mitigating $\mathrm{CO}_{2}$ emissions" (IEA, 2010a).

Coal use has expanded 59\% between 1990 and 2010 and it is the world's fastest-growing fuel. All societies are concerned with the "Three Es" - energy, economy and environment. Socioeconomic progress in all three of these areas depends upon a broad number of variables, but in the electricity arena, progress will likely continue to be disproportionately dependent upon coal.

\section{Attributes of coal}

Abundance and accessibility: Coal is the world's most prevalent and widely distributed fossil fuel, accounting for $64 \%$ of global economically recoverable fossil resources compared to $19 \%$ for oil and $17 \%$ for natural gas. The amount of proven recoverable coal reserves exceeds one trillion tonnes. Coal is distributed across every continent and every region of the world. The Western Hemisphere itself has over 300 billion tonnes of coal, Europe has 73 billion and Australia over 75 billion. 
Secure energy: Coal reserves are distributed widely across the globe. This global distribution provides energy security across broad political arenas.

Reliability: Coal's abundance and distribution, coupled with its relatively low and stable price pattern, set the stage for a reliable supply of energy. In many countries, coal-based generation is one of the first sources to be dispatched throughout the electric grid. Coal's characteristics make

Page | 6 it a very attractive baseload fuel. Consistently, the amount of electricity generated from coal significantly exceeds coal's relative capacity compared to other fuels. In 2009, for instance, coal accounted for only $32 \%$ of total generation capacity but produced $41 \%$ of the world's electricity.

Affordability: Based on IEA analyses of levelised costs of electricity, supercritical plants are one of the most affordable sources of power generation in China, costing USD 33/MWh compared to USD 50 for hydro, USD 53 for nuclear and USD 71 for wind (IEA, 2010c). China is projected to build between $500 \mathrm{GW}$ and $1000 \mathrm{GW}$ of new coal capacity over the next 25 years.

Versatility: Countries around the world have been initiating an increasing number of projects converting coal to liquid fuel, substitute natural gas or chemicals. The scale of China's coal conversion plans is especially informative and indicates that the goal is to develop an additional 1.2 billion tonnes of coal over the next decade and to utilise that coal in various conversion projects (Jiachun, 2010). Furthermore, coal-to-liquids (CTL) will gain increasing importance with the approach of global peak production of conventional oil.

\section{Conclusion}

Coal can continue to contribute as an energy source to aid global efforts to eradicate poverty, expand economic growth and meet climate change goals. Clean coal technologies, especially high-efficiency power generation and CCS, are the pathways to unlocking the extensive reserves of coal widely dispersed across the globe. Given the attributes of coal and the contribution of advanced technologies, the road leading from the Copenhagen Accord can be outlined as follows:

- eliminate energy poverty as a first-order priority;

- create access to energy for everyone, everywhere by 2050;

- advance all energy forms for long-term, sustainable access; and

- commercialise and deploy advanced clean technologies to eventually reach near-zero emissions from coal and natural gas power plants.

Dramatically reducing $\mathrm{CO}_{2}$ emissions is a major challenge but it is tractable through continuously evolving technologies. The parallel question is whether the world will actually deliver on the second promise out of Copenhagen - eradication of poverty and energy deprivation. Current IEA projections indicate that 1.2 billion people will still be without electricity in 2030 (IEA, 2011b). Just as importantly, perhaps as many as two billion others will have only sporadic and limited access to power. 


\section{Coal in the global context}

The central themes of this document revolve around the global value of coal and the opportunities clean coal technologies present to continue and expand utilisation of this vast energy resource, thereby supporting progress toward the world's socio-economic and environmental goals. In Energy Technology Perspectives 2010, the IEA concludes:

"Concern about energy security, the threat of climate change and the need to meet growing energy demand (particularly in the developing world) all pose major challenges to energy decision-makers...a portfolio of existing and new technologies will be needed to address these challenges."

IEA, 2010a.

The commercialisation and deployment of the next generation of clean coal technologies, particularly (a) higher efficiencies and (b) carbon capture and storage (CCS), will be central components of this developing portfolio and enhance steady progress toward the final goal of near-zero emissions.

\section{Introduction}

The planet is now home to 7 billion people. Supporting a population of 6.8 billion in 2009 required a total energy supply the equivalent to over 11 billion tonnes of oil, or 22 billion tonnes of coal or 10 trillion cubic meters of natural gas. The scope of economic growth is now reaching unprecedented levels with world gross domestic product (GDP) approaching USD 70 trillion in 2009. The energy requirements necessary to support this commercial activity cannot be attained by any one fuel alone. The scale of energy demand is simply too large. Thus, energy industries and markets have organised to embrace a range of primary energy sources to supply the global requirements for heat, light and motive power. Coal has been, is and will continue to be a major source of energy for billions of people around the globe.

The world consumed almost 7 billion tonnes of coal during 2010. Coal is the second-largest source of primary energy, providing more than $27 \%$ of total energy demand, just behind the $33 \%$ that petroleum contributes. Natural gas supplies $21 \%$. Thus, fossil fuels account for $81 \%$ of the world's primary energy demand. Biomass provides $10 \%$, nuclear $6 \%$ and hydro $2 \%$. While renewable energy has been growing briskly in recent years, it supplies less than $2 \%$ of global energy requirements. With rising levels of affluence, the growth of future energy demand will likely exceed the supply capability of renewable energy, requiring fossil fuels to make up the balance of growth. The net result is that fossil fuels will remain the dominant source of energy for the world economy in the coming decades.

Among fossil fuels, coal is the generally the most economically competitive with the lowest price on a heat equivalency basis compared with prices for natural gas and oil. Given this cost advantage, both developed and developing countries use coal to produce power. Low-cost, abundant coal enables the large-scale provision of inexpensive electricity. The widespread adoption of electricity improves overall environmental quality and enables higher standards of living. For example, electric lighting is much less expensive than kerosene lamps and reduces indoor air pollution, which is a major source of environmental health problems in developing countries. Low-cost electricity also powers water pumps, which allow the distribution of potable water and the reduction of water-borne parasitic diseases that seriously impair the health and 
well-being of hundreds of millions of people. Reliable and cost-efficient electric power also promotes the adoption of electric motors in manufacturing and the use of modern computers and information systems that substantially improve productivity, enabling consumers and producers to more efficiently produce, distribute and consume goods and services.

Apart from electricity, coal is essential in infrastructure development. Metallurgical grade coal is Page | 8 used to produce coke, a material used as both a fuel and as a source of carbon to reduce iron ore to molten pig iron, which is later smelted into finished steel products. Steel is used in a multitude of applications and is by far the most important industrial construction material. Water systems, subways, bridges, skyscrapers, wind turbines, pipelines, offshore oil platforms and other modern infrastructure systems are built with steel. The option to produce steel without coke is to melt iron and steel scrap in electric arc furnaces to make new steel. China and other developing countries cannot adopt this option on a large scale because they have very limited domestic supplies of iron and steel scrap. Further, electricity to power the electric arc furnaces frequently comes from coal.

Coal also provides a critical backstop energy resource for the production of liquid fuels used in manufacturing and transportation. A peak in world oil production is almost certain to occur at some time during this century. As this time approaches, the real price of oil and petroleum products will escalate and provide incentives for the entry of substitutes. Coal is well-positioned to contribute to world liquid fuel production. With extensive reserves, economies of scale in extraction, and new technologies to convert CTL and to capture and store GHG emissions, coalbased liquid fuel systems and electricity could be quite competitive with alternative transportation systems. Several countries, especially China, are already building CTL plants and other coal conversion facilities. As conventional peak oil approaches, the option of using coal for liquid fuel production will increase in value, especially with the deployment of CCS.

The provision of secure, low-cost, reliable electricity, the production of infrastructure and the option to produce liquid fuels are three specific ways in which coal directly contributes to greater economic growth, job creation, and higher personal income and wealth. As Figure 1 demonstrates, the demand for coal has risen accordingly.

Figure 1 The growth of coal consumption

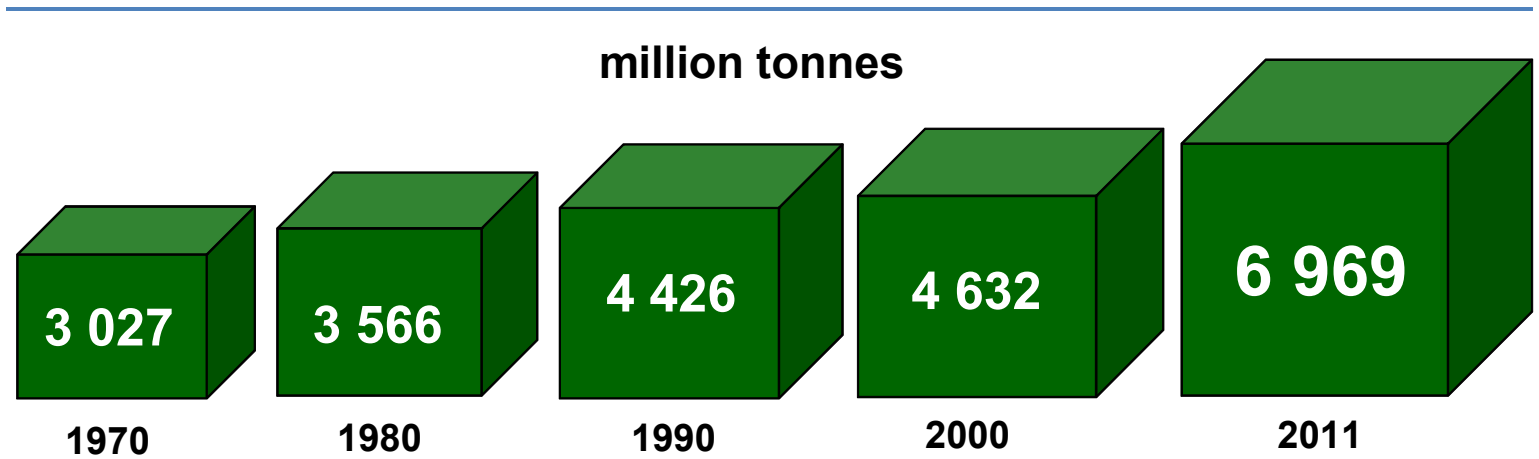

Source: BP Statistical Review of World Energy, 2010.

\section{The global challenges from Copenhagen}

The Copenhagen Accord (2009) identified two crucial challenges at the global level: first, the need to "bear in mind that social and economic development and poverty eradication are the first and overriding priorities of developing countries." Second, the need for the nations of the world to meet the growing challenge of climate change and "cooperate in achieving the peaking of global 
and national emissions as soon as possible." The challenges are real and substantial. On the one hand, over 1400 million people are totally without electricity and at least another 2000 million have highly constrained access to electricity (Figure 2).

Figure 2 The global scope of poverty and electricity deprivation relative to the size of the European Union

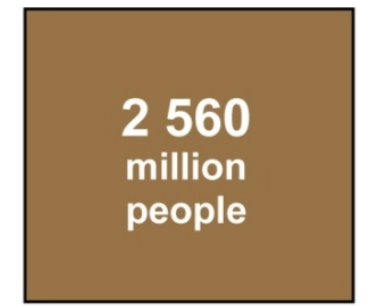

Live on Less Than USD 2 a Day
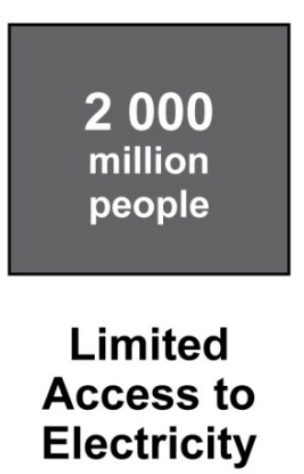

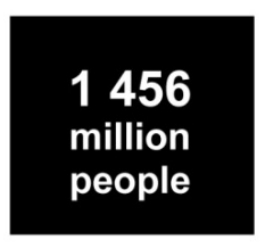

Have No Electricity At all

Sources: Developed from World Bank, 2009 and 2010b; and IEA, 2010e.

At the same time, calls to reduce emissions by more than $80 \%$ by 2050 face the powerful headwind of rising energy demand occasioned by economic growth, increases in population and an ever-greater proportion of people living in cities (Figure 3).

Figure 3 The scale of the environmental challenge by 2050

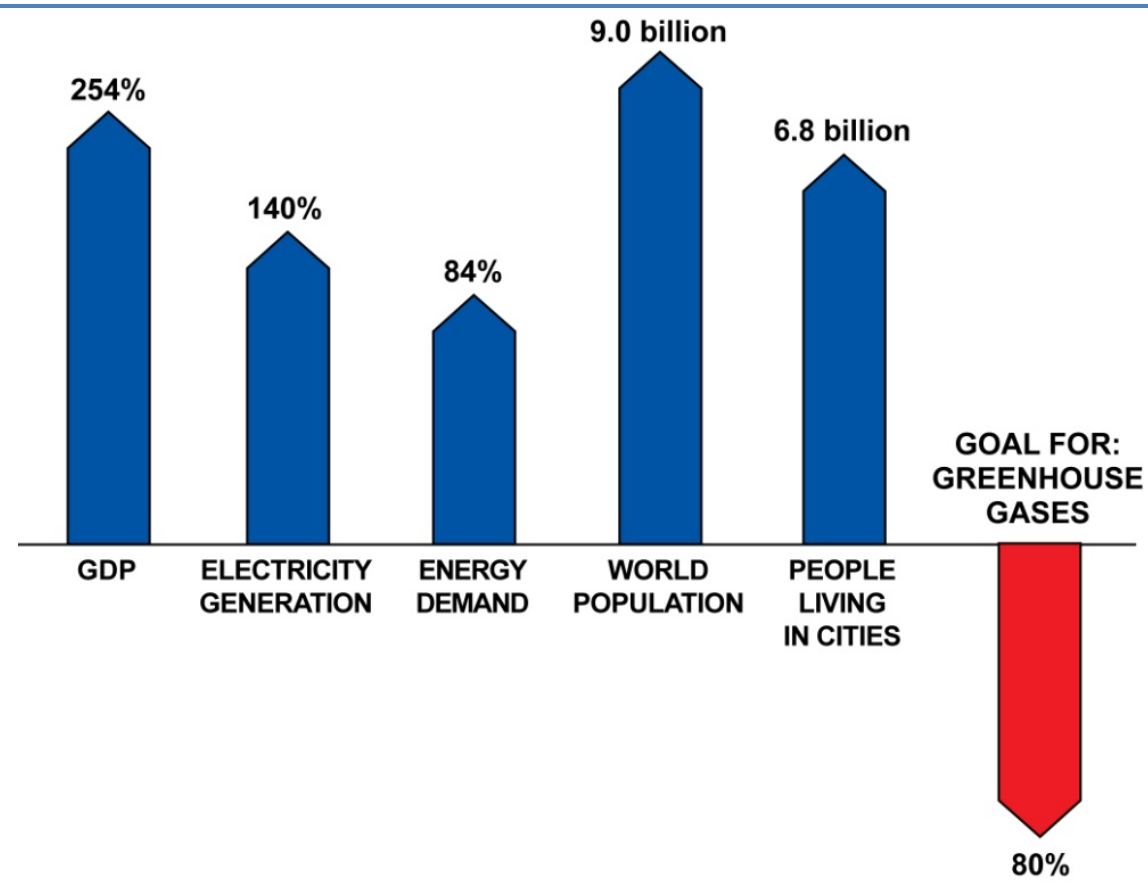

Source: Developed from EIA, 2010a; IEA, 2009a; World Bank, 2010b; trend data through 2050.

The world needs much more energy, particularly electricity, while at the same time there is a growing desire to significantly reduce greenhouse-gas emissions including those of $\mathrm{CO}_{2}$. Energy is, and will continue to be, the linchpin of the social and economic development called for in the Copenhagen Accord. Figure 4 shows the correlation between energy use and GDP. 


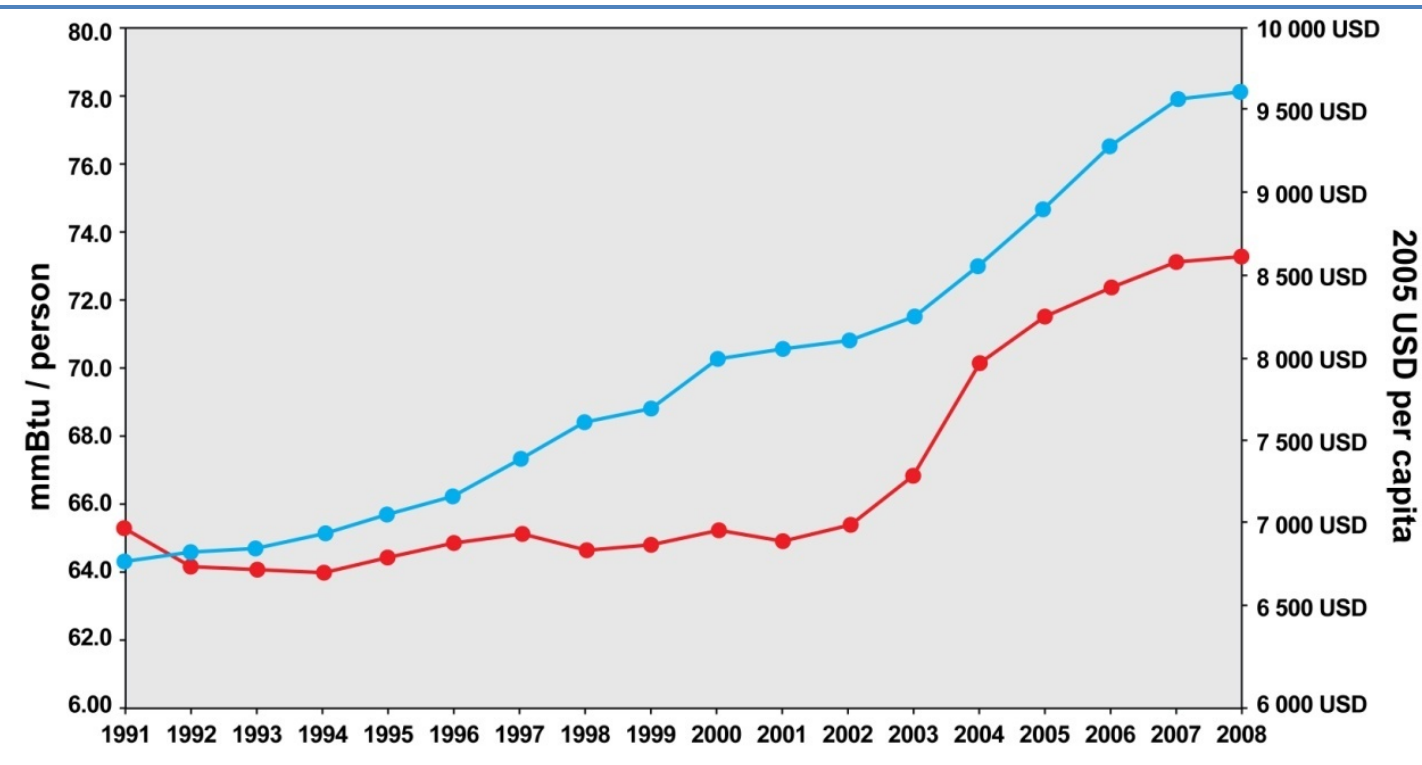

$\bullet$ Per Capita Energy $\bullet$ Per Capita GDP

Source: EIA, 2010a.

Energy is essential in transforming agrarian societies to modern industrial ones. This societal transformation, driven by the accumulation of income and wealth, reduces many contagious diseases, reduces child mortality and lengthens adult life expectancy. This cycle has been demonstrated over the past two centuries in countries around the world, but in a $\mathrm{CO}_{2}$ constrained world, energy production will have to be cleaner and more efficient. The emergence from poverty begins as countries develop extensive transportation structures using petroleum and build electricity networks, often based upon coal. These systems are capable of achieving massive economies of scale that provide large amounts of energy at low cost. Such abundant and reliable supplies of energy spur technological change, enhance productivity growth and elevate living standards.

The fact that the global economy currently derives over $80 \%$ of its total energy from coal, oil and natural gas reflects the current competitive advantage of fossil fuels. These fuels have empowered modern industrial societies to improve the quality of life for billions of people. The Industrial Revolution in Western Europe and the United States was arguably the most significant socio-economic transformation in human history. From the late 1700 s to the early 1900s, societies such as England, Germany, France and the United States were forever altered by a converging set of macro trends: industrialisation, urbanisation and modernisation, and more recently, an electronic information revolution.

These four macro trends all required - and will continue to require - ever-increasing amounts of energy to move people, goods, information and ideas, to control the immediate environment, to manufacture products, and to grow, preserve and process food. For most of the past century, Western Europe and the United States, eventually joined by Japan, found themselves front and centre on the global energy stage. By 1980, for example, five nations (Germany, France, Japan, the United Kingdom and the United States) accounted for half the world's energy consumption despite having only $12 \%$ of the world's population.

Large portions of the rest of the world are now beginning the same march to prosperity - China, with 1.34 billion people, and India, with 1.15 billion people, are the two most obvious examples. But following the same path are countries such as Brazil, South Africa and a number of nations in 
Southeast Asia. As Figure 5 shows, for every person under age 15 in the European Union, for example, there are almost six in India and more than four in China. Moreover, while the median age in the European Union is 40, in India it is 26.

Figure 5 The coming wave of rising expectations

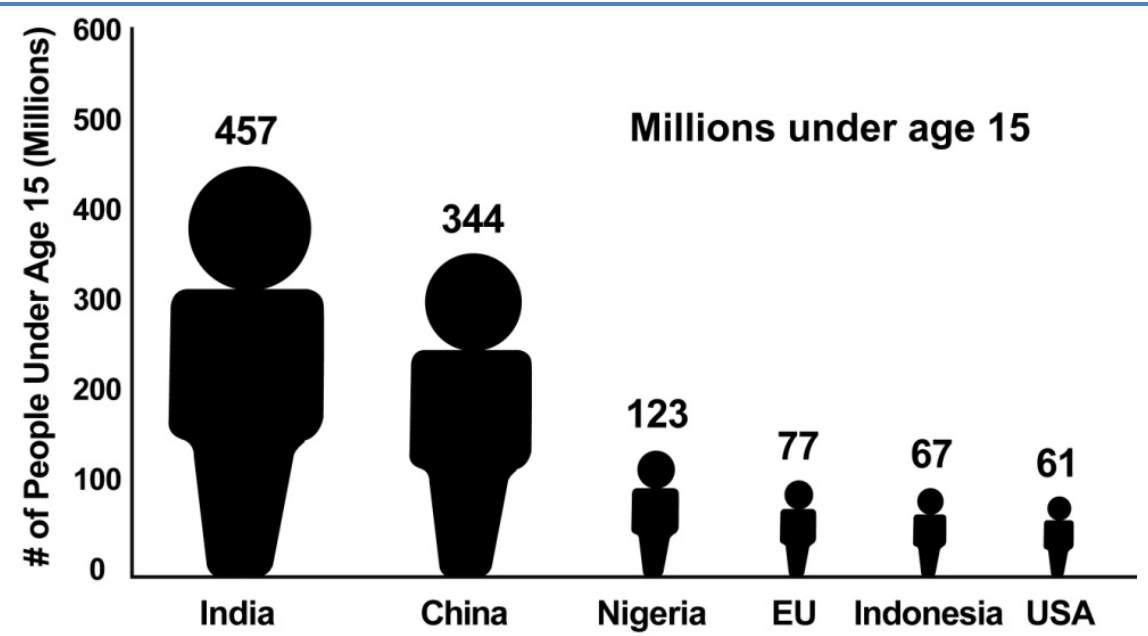

Source: CIA World Fact Book, 2010.

The implications of these differences in age distribution are profound as socio-economic expectations rise around the world, steadily fuelled by ever-more-available electronic communication. For example, Dargay et al. (2007) project that by 2030, China will add 370 million vehicles to its fleet and India will add 140 million. By comparison, Japan, Germany, France, the United Kingdom and Italy will only add a combined 51 million vehicles.

\section{Urbanisation}

Urbanisation has been a central driving force of steadily increasing energy consumption for the last two centuries. In 1800 , only $2 \%$ of the global population lived in cities. By 1950 , it was $30 \%$ and by 2000 , urbanisation had reached $47 \%$. This accelerating trend soon led to half the world's population living in urban areas by 2007 . By 2030 , more than five billion people $-60 \%$ of the global population - will live in cities.

This increasing agglomeration of populations has major implications for the consumption of material goods (steel, cement, copper, aluminium, plastics) and, of course, for the force which drives it all - energy, especially electricity. Urbanisation is strongly correlated with energy consumption. In China, one of the most rapidly urbanising nations in the world, households in cities consume over 3.6 times more commercial energy than their rural counterparts (World Bank, 2008b).

In addition, the link between urbanisation and modernisation propels a rising need for communication and information processing. The demand for these technologies has exploded around the world (Boston Consulting Group, 2010).

- Almost one-quarter of the world's population now has access to the Internet -1.7 billion people. In developed regions, the percentage with access to the Internet is $60 \%$.

- Global subscriptions to mobile cellular services number over five billion - over $70 \%$ of people.

- The global television market has about 1.22 billion households with at least one television. 
This demand for communications and information technology (ICT) and computer electronics (CE) is projected to increase steadily over the next decade, requiring not only more electricity, but also enhanced reliability throughout the entire power delivery system. The IEA (2009c) has stated that by 2030 "global electricity used by household ICT and CE equipment could rise to 1700 TWh, requiring the addition of approximately $280 \mathrm{GW}$ of generating capacity."

Page | 12

\section{The role of coal}

For well over 150 years, many parts of the world have increasingly relied on coal to meet rising energy demand and support economic growth (Figure 6). Coal was the backbone of the Industrial Revolution in England during the $18^{\text {th }}$ century, America's emergence as a major economic power during the late $19^{\text {th }}$ and $20^{\text {th }}$ centuries, Germany's manufacturing prowess during the early $20^{\text {th }}$ century, and Japan's rise at approximately the same time. Coal is fuelling the $21^{\text {st }}$ century socioeconomic change occurring in China.

Figure 6 Global coal consumption and economic growth

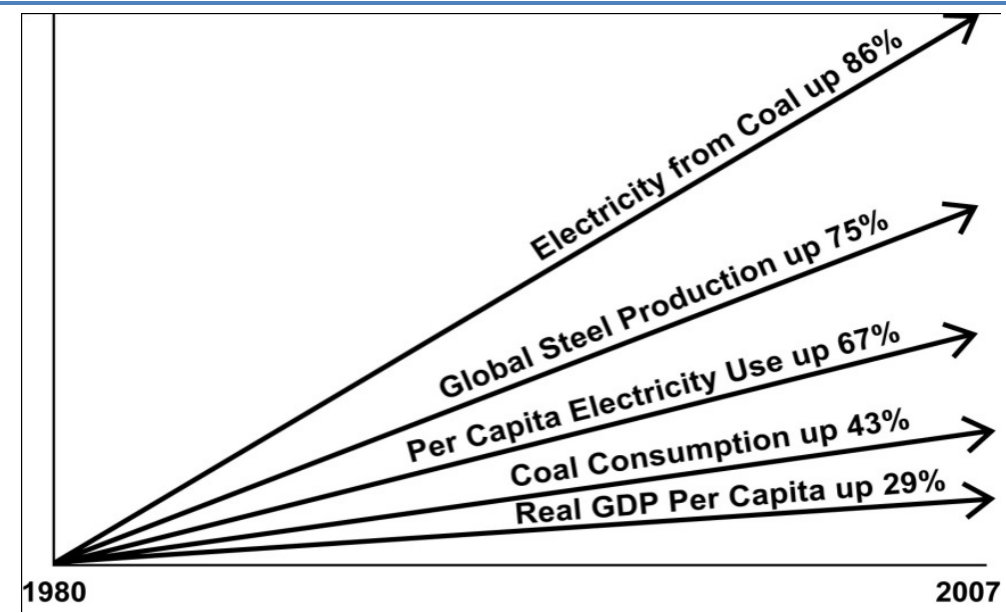

Source: Developed from data from World Steel Association, 2010; EIA, 2010a; IEA, 2009b; and BP, 2010.

Further, global reliance on coal is projected to continue to increase as India and other developing countries seek a better life for their citizens. In fact, in the IEA New Policies Scenario, coal consumption is projected to increase $24 \%$ by 2035 , compared to 2009 . In the Current Policies Scenario, a $65 \%$ increase is projected. From 1990-2035, based on a population increase of 3.2 billion people and economic growth of over USD 125 trillion, coal is projected to actually increase its contribution to global energy consumption between 1900 and 3200 million tonnes of oil equivalent.

Nowhere is this growing demand for coal more apparent than in the production of electricity. Over the last 40 years, coal-based electricity at the global level has increased $300 \%$ - from 2100 TWh in 1971 to approximately 8500 TWh in 2010. Based on the IEA New and Current Policies projections (Table 1), coal-based generation will need to provide even more power over the next several decades. 
Table 1 Projected incremental sources of electricity through 2035

\begin{tabular}{|c|c|c|c|c|c|}
\hline $\begin{array}{l}\text { Source of } \\
\text { incremental } \\
\text { electricity }\end{array}$ & $\begin{array}{l}2009 \text { actual } \\
\text { in TWh }\end{array}$ & \multicolumn{4}{|c|}{ Scenario } \\
\hline Coal & 8118 & 12035 & $48 \%$ & 16932 & $109 \%$ \\
\hline Gas & 4299 & 7923 & $84 \%$ & 8653 & $101 \%$ \\
\hline Hydro & 3252 & 5518 & $70 \%$ & 5144 & $63 \%$ \\
\hline Wind & 273 & 2703 & $890 \%$ & 2005 & $634 \%$ \\
\hline Biomass & 288 & 1497 & $420 \%$ & 1150 & $299 \%$ \\
\hline
\end{tabular}

Note: Data presented derive largely from the New Policies and Current Policies Scenarios presented in the World Energy Outlook 2011. Various alternative scenarios regarding energy production and consumption could be presented, as discussed later in this section.

Source: Developed from IEA, 2011b.

Various other scenarios regarding energy production and consumption have been presented by IEA (Table 2) in regard to electricity generation patterns out to 2050. Several of these are BLUE Map Scenarios. For a detailed review of these scenarios see IEA's Energy Technology Perspectives 2010. The BLUE Map Scenarios target 50\% reduction in energy-related $\mathrm{CO}_{2}$ emissions by 2050 . The $\mathrm{CO}_{2}$ emissions from power generation are projected to be reduced by $76 \%$. Renewables would account for $48 \%$ of power generation and nuclear $24 \%$. Other assumptions made can be found on page 48 of Energy Technology Perspectives 2010.

Table 2 IEA scenarios of global electricity production by energy source

\begin{tabular}{|c|c|c|c|c|c|c|}
\hline \multirow[t]{2}{*}{ Production (TWh) } & \multirow[t]{2}{*}{2007} & \multicolumn{5}{|c|}{2050} \\
\hline & & Baseline & BLUE Map & $\begin{array}{c}\text { BLUE } \\
\text { no CCS }\end{array}$ & $\begin{array}{c}\text { BLUE } \\
\text { High Nuc. }\end{array}$ & $\begin{array}{c}\text { BLUE } \\
\text { High Ren. }\end{array}$ \\
\hline Nuclear & 2719 & 4825 & 9608 & 9608 & 15859 & 4358 \\
\hline Oil & 1117 & 311 & 226 & 148 & 170 & 197 \\
\hline Coal & 8216 & 20459 & 238 & 1164 & 211 & 330 \\
\hline Coal + CCS & 0 & 0 & 4746 & 0 & 3395 & 910 \\
\hline Gas & 4126 & 10622 & 4283 & 6939 & 2840 & 2983 \\
\hline Gas + CCS & 0 & 0 & 1815 & 0 & 1536 & 771 \\
\hline Hydro & 3078 & 5344 & 5749 & 5582 & 4747 & 6043 \\
\hline Biomass/waste & 259 & 1249 & 2149 & 2703 & 2044 & 2488 \\
\hline Biomass + Ccs & 0 & 0 & 311 & 0 & 251 & 146 \\
\hline Geothermal & 62 & 297 & 1005 & 1007 & 932 & 1411 \\
\hline Wind & 173 & 2149 & 4916 & 5589 & 3943 & 8193 \\
\hline Ocean & 1 & 25 & 133 & 274 & 99 & 552 \\
\hline Solar & 5 & 905 & 4958 & 5512 & 4113 & 9274 \\
\hline Total & 19756 & 46186 & 40137 & 38526 & 4014039 & 37656 \\
\hline
\end{tabular}

Source: Developed from IEA, 2010a. 
As the data in Table 2 demonstrate, the BLUE Map Scenarios of the IEA assume substantial impacts from energy efficiency and conservation and depend upon electricity production levels ranging well below the Baseline Scenario. Coal-based electricity would be significantly reduced in each case and other sources of electricity would have to make up the generation shortfall. In the BLUE Map Scenario, for example, nuclear power would account for twice the electricity in 2050 as currently projected. In the BLUE Map high nuclear case, nuclear would account for more than three times the current projection. In the BLUE Map high renewable case, wind would account for about four times the current 2050 wind projection, solar 10 times the current baseline, and geothermal upwards of five times the baseline.

It is worth noting that the IEA BLUE Map Scenarios require the deployment of some technologies that are not commercially available today, and a carbon price of up to USD 175/tonne of $\mathrm{CO}_{2}$ (IEA, 2010a). Clearly, replacing coal generation would require substantial additional natural and financial resources. Given the cost and materials to develop these alternative sources of electricity at the scale needed to replace coal, the IEA has stressed the importance of CCS in mitigating $\mathrm{CO}_{2}$ emissions (IEA, 2010a). Figure 7 presents a conceptual overview of one path - among others - to approach near-zero emissions from coal over the next several decades.

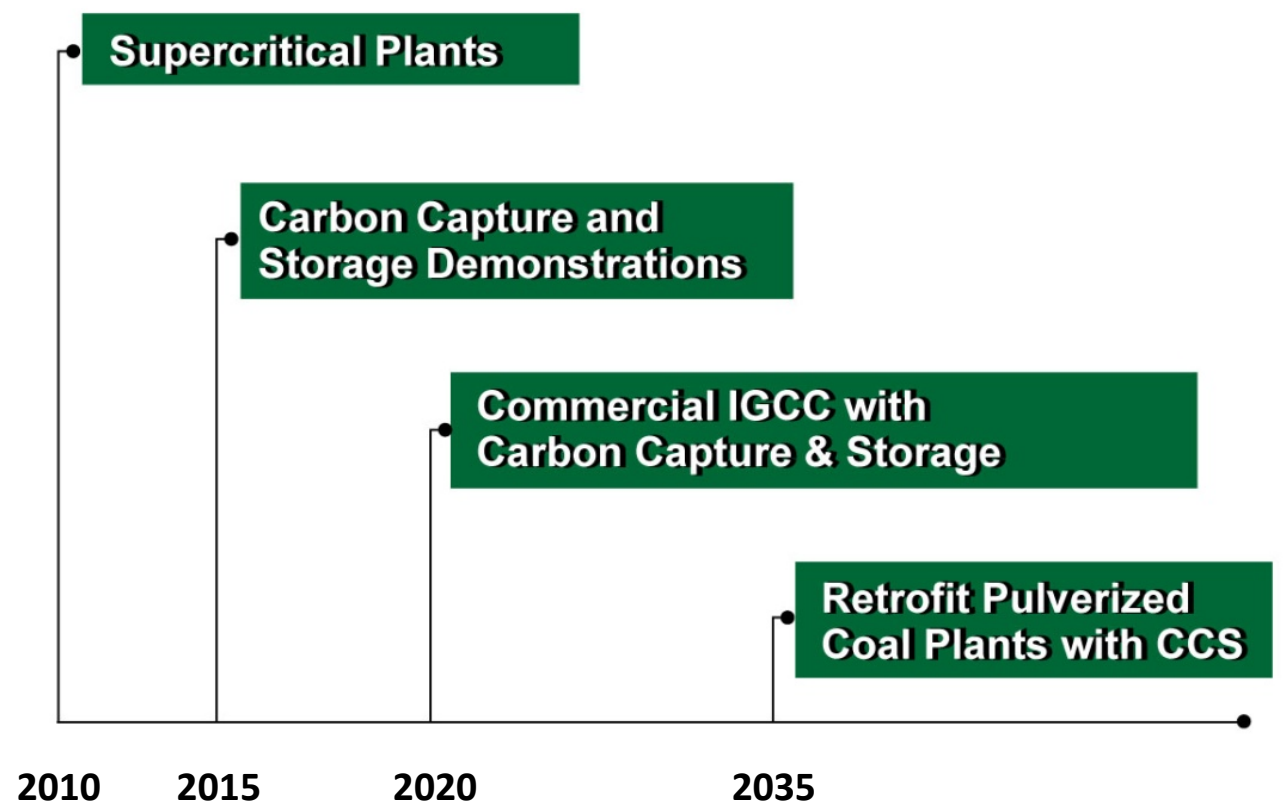

As Figure 7 shows, retrofitting coal with CCS will be an important component of emissions reduction. The IEA has estimated that about $16 \%$ of the total coal-based electricity generating capacity operating with CCS in 2050 will be plants that have been retrofitted (IEA, 2010a). To the extent that this percentage could be significantly expanded, $\mathrm{CO}_{2}$ emissions reductions would decrease accordingly. The IEA has stressed the "importance of ensuring new plants built over the next 10 to 20 years have CCS fitted from the outset or be ready for retrofitting as soon as it can be achieved" (IEA, 2010a). 


\section{The rise of electricity}

Electricity is the sine qua non of modern society. The US National Academy of Engineering (2004) identified societal electrification as the "most significant engineering achievement" of the $20^{\text {th }}$ century - a century that saw a world population growth of over four billion people, the rise of the metropolis, a transportation revolution, dramatic improvements in medical care and the Page|15 emergence of a vast system of electronic communication.

The quotation by The New York Times (box underneath Figure 8) is as relevant to developing countries today as it was to the now-developed countries in the 1930s.

Figure 8 Access to electricity means a higher quality of life

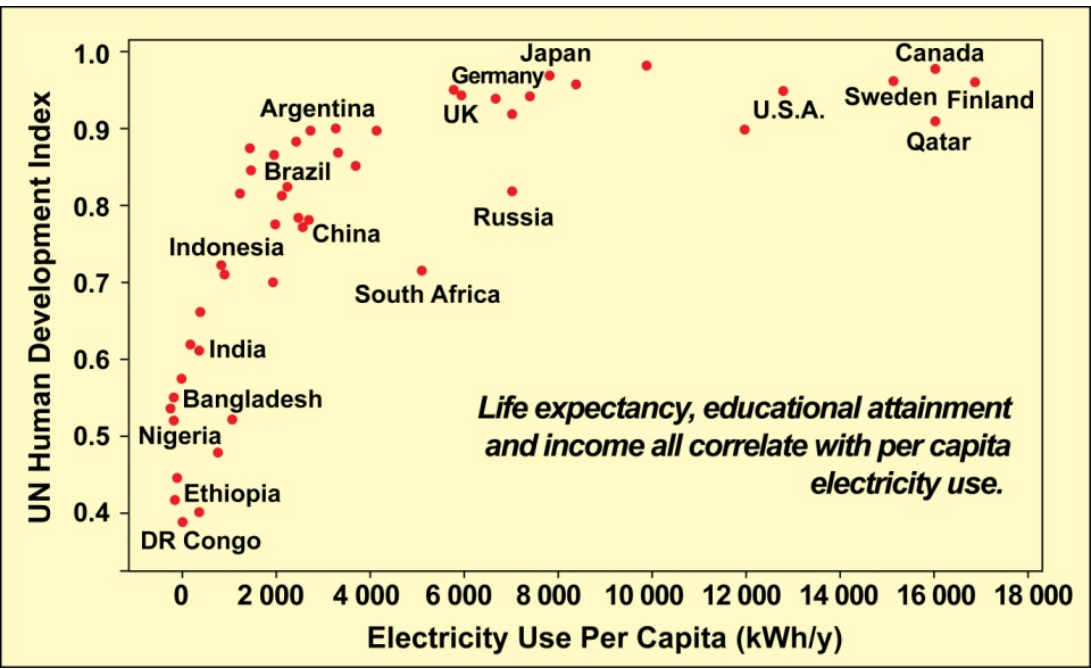

Source: Developed from World Bank, 2009.

In 1930, The New York Times stated: "Nothing in modern life so raises the standard of living of high and low income groups as the use of electricity."

Electricity is unique and convertible to virtually any energy service - light, motion, heat, electronics and chemical potential. Electricity permits previously unattainable precision, control and speed, and provides temperature and energy density far greater than energy sources it has replaced. Electricity has no inertia, is instantaneous and $100 \%$ convertible to work.

Further, electricity has wide-ranging environmental benefits. Electro-technologies are more efficient than their fuel-burning counterparts and, unlike standard fuels, have no waste products at the point of use - no smoke, ash, combustion gas, noise or odour. In short, electrification increases the efficiency of society's primary energy consumption and reduces emissions that are damaging to health.

In addition, environmental management depends upon electricity for the movement of water and waste. A sustainable environment requires clean water and sanitation facilities. Electricity is the key to providing these services and pollution controls. In societies where per-capita electricity consumption is $350 \mathrm{kWh} / \mathrm{year}$, access to improved sanitation averages about $38 \%$. In contrast, societies where per-capita electricity consumption is over $6000 \mathrm{kWh} /$ year display $100 \%$ access to improved sanitation (World Bank, 2010a). Coal is the predominant fuel for electricity generation globally (Figure 9). 
Figure 9 Electricity production from coal 2009

Page | 16

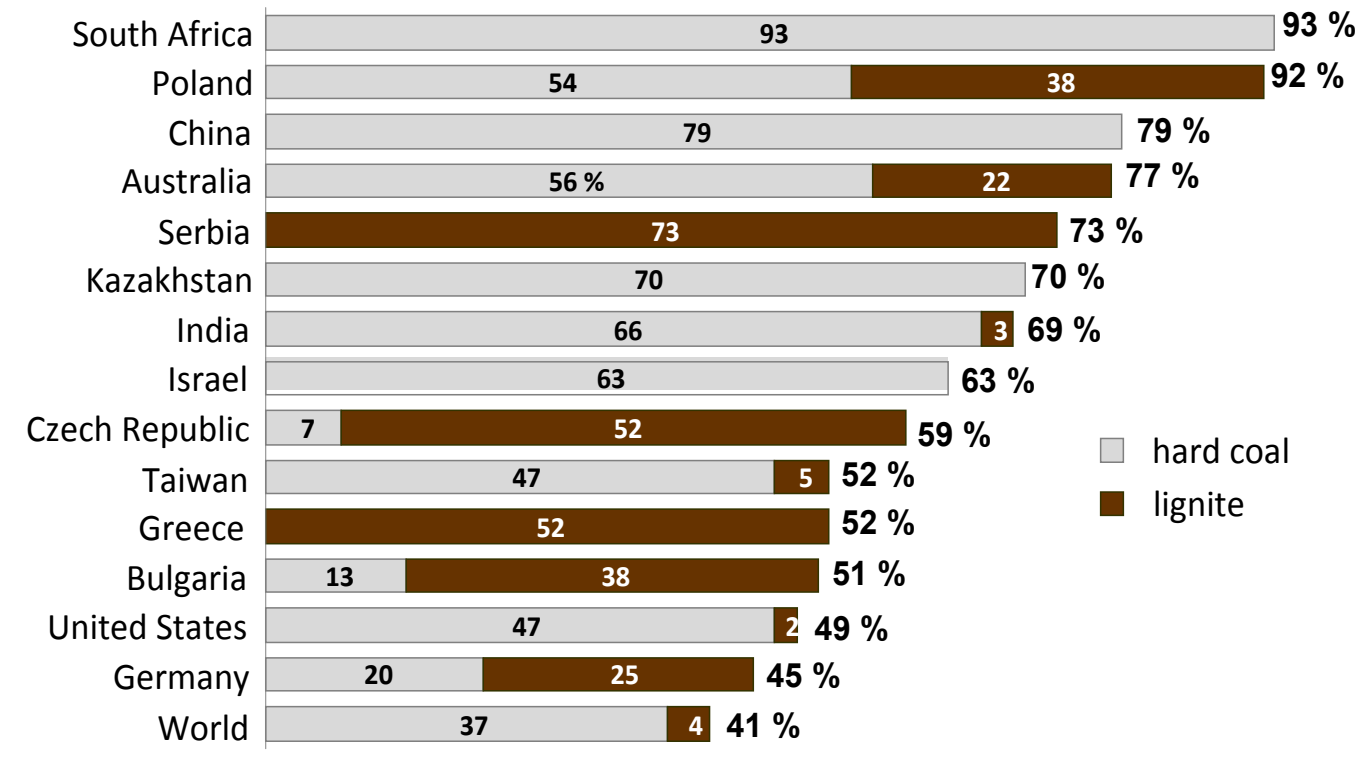

Source: Developed from IEA, 2011.

Given the characteristics of electricity, it is no surprise that demand for electric power has steadily increased across the globe and is projected to continue this upward momentum (Figure 10).

Figure 10 Historical and projected global electricity generation (TWh)

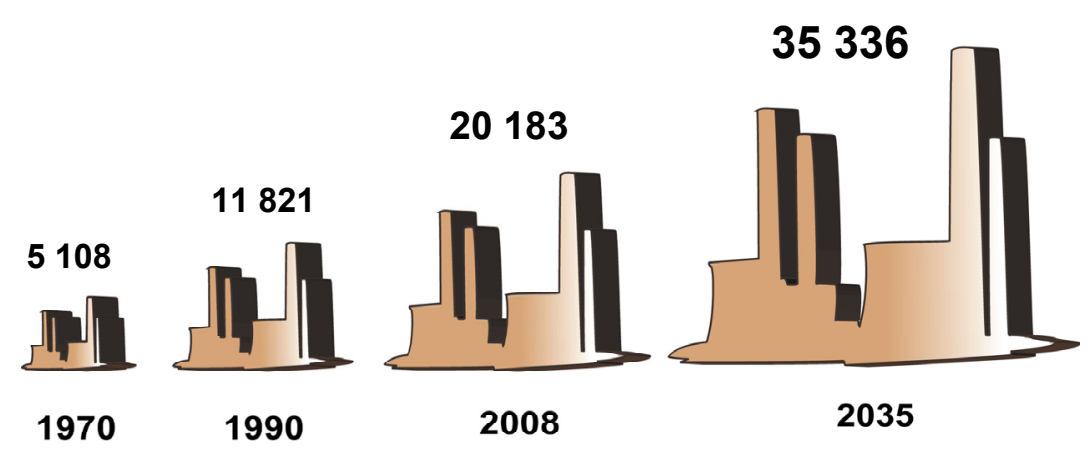

Source: IEA 2002, 2009a and 2011b (New Policies Scenario for 2035).

"...electrification greatly improves the quality of life. Lighting alone brings benefits such as increased study time and improved study environment for school-children, extended hours for small businesses, and greater security."

World Bank, 2010a.

To meet this growing energy demand, societies must generate a continually increasing amount of electric power. For decades, fossil fuels have provided the great bulk of that electricity. In 1970, for example, fossil fuels (oil, coal, and natural gas) accounted for $73 \%$ of global electric power. In 2009 , fossil fuels provided $67 \%$ of electricity. The number of TWh of generation produced by fossil fuels increased from 3800 TWh in 1970 to 13444 TWh in 2009. This $254 \%$ increase of 9644 TWh was the equivalent of nine times the current generation in Japan. Almost two-thirds of this incremental growth in fossil fuel generation came from coal alone. 


\section{The scale of global poverty and electricity deprivation}

People in societies with greater access to electricity are more likely to survive childhood, eat healthier, drink cleaner water and are better educated. Women and children are among the greatest beneficiaries of electrification as new doors of opportunity open for these especially vulnerable segments of the population. UNICEF (2009) has estimated that over 24000 children die each day from poverty-related conditions, significantly exacerbated by electricity deprivation.

Almost $70 \%$ of all people living in poverty are female (CARE, 2010). The continuing problem of "feminisation of poverty" will be impossible to resolve unless those households have adequate access to electricity and other forms of energy. In most countries, household tasks requiring energy are typically delegated to women and children - gathering wood, carrying water, cooking. These chores are made easier, safer and healthier with the availability of electricity whereas lack of electricity perpetuates the cycle of poverty by preventing access to electronic communication; it can also mean inadequate illumination for reading and studying at night. Breaking the global pattern of poverty depends upon available and affordable energy in general, and on access to electricity, in particular (Figure 11).

Figure 11 The scope of electricity deprivation

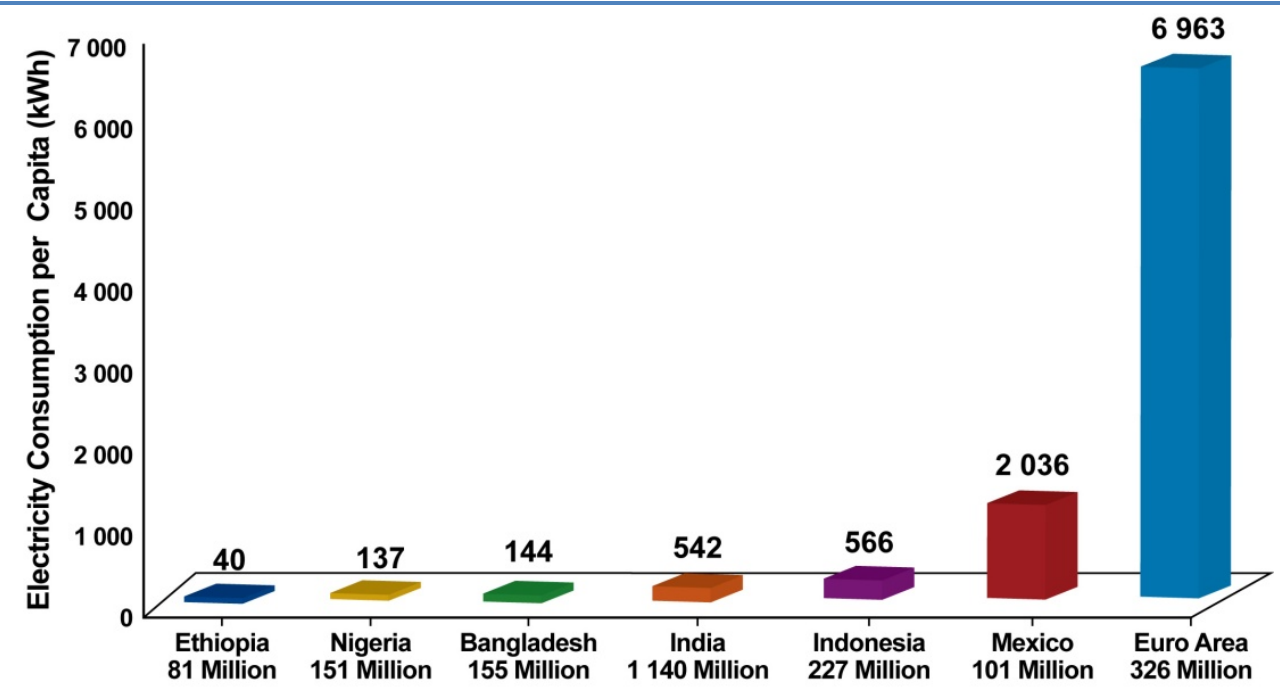

(Population)

Source: World Bank, 2010b.

Over 4 billion people, at least $60 \%$ of the world's population, use fewer than $2350 \mathrm{kWh}$ per year, or roughly only one- third as much as the European Union average.

Since 1980, global electricity generating capacity has increased from $1985 \mathrm{GW}$ to over $4950 \mathrm{GW}$ in 2009 - an increase of some $150 \%$. By 2035, an additional $4081 \mathrm{GW}$ of capacity is projected by the IEA New Policies Scenario and 4169 by the Current Policies Scenario. In other words, in only a half century, the world will have added over $7000 \mathrm{GW}$ of electric generation capacity - an increase of more than $250 \%$. Despite this significant growth in electricity, Figure 12 illustrates that energy poverty will still persist beyond 2030. 
Figure 12 The persistence of energy poverty

2000

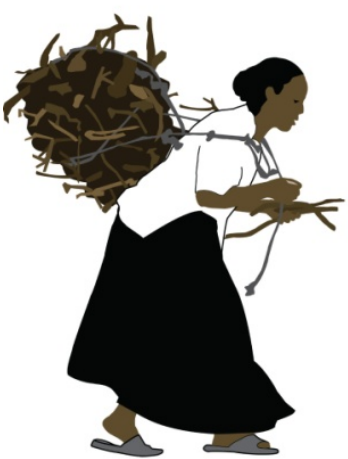

1640 million lacked electricity
Today

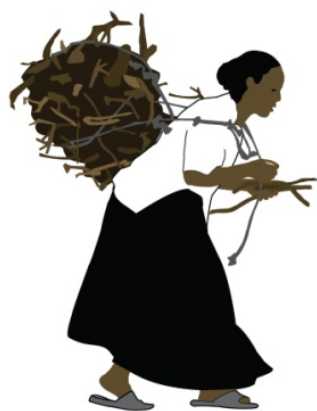

1496 million lack electricity
In 2030

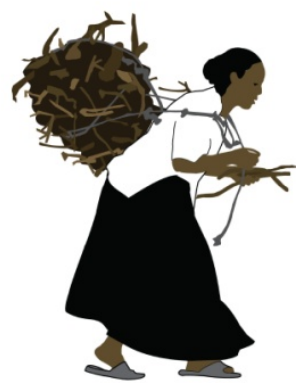

1200 million will lack electricity

Source: Developed from IEA, 2010d.

"This situation is set to change very little over the next 20 years, actually deteriorating in some respects. This is shameful and unacceptable."

IEA, 2010e.

Importantly, even if a village is formally defined as "electrified" that does not mean everyone has access to electricity (World Bank, 2010a). For example, in Lao PDR, even after almost 15 years of village electrification, only a little more than $80 \%$ of households have electricity. In the Philippines, after close to 25 years of electrification, over $22 \%$ of households still lack electric power. Finally, in Thailand, the percentage of households in electrified villages that remain unconnected after more than two decades is $25 \%$.

If the goal of eliminating energy poverty and deprivation is ever to be attained, the supply and affordability of energy, particularly electricity, must improve dramatically. The scale that will be required to meet these goals cannot be met by one fuel but will require the continued and increasing availability, production and consumption of all primary energy sources, including coal. 


\section{Coal-driven progress in China serves as a model for development}

"Electrification in China is a remarkable success story...the most important lesson for other developing countries [is] that electrified countries reap great benefits, both in terms of economic growth and human welfare...China is an example for the developing world."

IEA, 2007.

In 1970, China had little external economic activity and limited modern development: over 600 million people lacked electricity, the below-age 5 death rate was 120 per 1000 children, only 1 in 500 people had a telephone, and the GDP per capita was USD 122.

Through a series of Five-Year-Plans, however, China utilised increased energy production, especially coal-based electricity, to catapult itself to the centre of the world's economic stage. For example, in just 15 years (1990-2005), China provided access to electricity to over 450 million people -1.5 times the current population of the United States.

This unprecedented expansion of the electricity supply system positively affected many communities, institutions, businesses, families and individuals in China. The electrification of both the cities and the countryside established an energy infrastructure that underlies China's historic move toward modernisation. In China today, $97 \%$ of the population has access to electricity (IEA, 2010d).

To meet the growing demand for energy, China turned to its most plentiful, stable, versatile and affordable resource - coal. China has only $3 \%$ of the world's oil and natural gas reserves but has $14 \%$ of its coal (BP, 2010). A new wave of Chinese policy makers recognised this asset early on and committed to making the country a "moderately well off society" by 2030 . Coal is seen as the least-cost option to move forward.

This plan is working. In terms of absolute numbers, no nation has made more progress toward the UN Millennium Development Goals than China. About $85 \%$ of the global population elevated from poverty since 1990 is Chinese (World Bank, 2010b). Chinese coal consumption has grown from $604 \mathrm{Mt}$ in 1980 to over $2800 \mathrm{Mt}$ in 2008. Utilisation of its coal resource enabled China to increase electricity output fivefold from 1990 to 2008 . Coal provided $65 \%$ of that increase. In the New Policies Scenario, coal is projected to fuel over $40 \%$ of the increase through 2035 (60\% in the Current Policies Scenario).

As leaders in other impoverished countries seek to utilise electricity to elevate the quality of life of their populations, many are currently turning to coal as an affordable and reliable fuel that can meet their needs at scale in a timely fashion. South Africa and India are proceeding with the development of coal power plants with the support of the World Bank.

\section{South Africa}

South Africa obtains over $90 \%$ of its electricity from coal and has developed extensive coal conversion projects, especially CTL. South Africa is part of the Southern African Power Pool (SAPP) and exports electricity to a number of countries in the area - including Botswana, Namibia and Mozambique - all countries where over half the population has no electricity and lives on less than two dollars per day. In South Africa itself, over 12 million people have no access to electricity and the life expectancy of the general population is 51 years. 
Based on a report to the World Bank (Davidson et al., 2010), over half of the infrastructure deficiencies that plague the sub-Saharan region can be attributed to limitations in the power sector. To meet the rapidly growing demand for electric power and alleviate the poverty that plagues the sub-Saharan region, Eskom, the major utility in South Africa, has initiated development of the Medupi Power Station, a coal-fuelled power plant currently under construction in Limpopo province with $4800 \mathrm{MW}$ of installed capacity and a second station, Kusile, also with $4800 \mathrm{MW}$, scheduled to begin operation in 2014. This combined $9600 \mathrm{MW}$ is $20 \%$ of current installed capacity. The World Bank has provided financial support for the project, which will be a crucial part of Eskom's and South Africa's ability to meet rising demand.

While South Africa is implementing construction of alternative sources of energy, especially wind and solar projects, along with efficiency improvements, as Pravin Gordhan (2010), South Africa's Minister of Finance, has stated: "The majority of our people remain poor and unemployment stands at an unacceptable $24 \%$. To sustain the growth rates we need to create jobs [relying on] our most abundant and affordable energy source: coal." South Africa has $4 \%$ of the world's coal (BP, 2010).

\section{India}

India generates $69 \%$ of its electricity from coal. While that percentage is projected to be $53 \%$ in the New Policies Scenario, it is maintained in the high 60s through 2035 in the Current Policies Scenario. Substantial amounts of incremental electricity will be needed. The extent of energy deprivation in India is difficult for most citizens of developed countries to comprehend. Almost $40 \%$ of the population on the subcontinent lacks access to electricity and the benefits such access brings to the quality of life.

Figure 13 The scale of electricity poverty in India

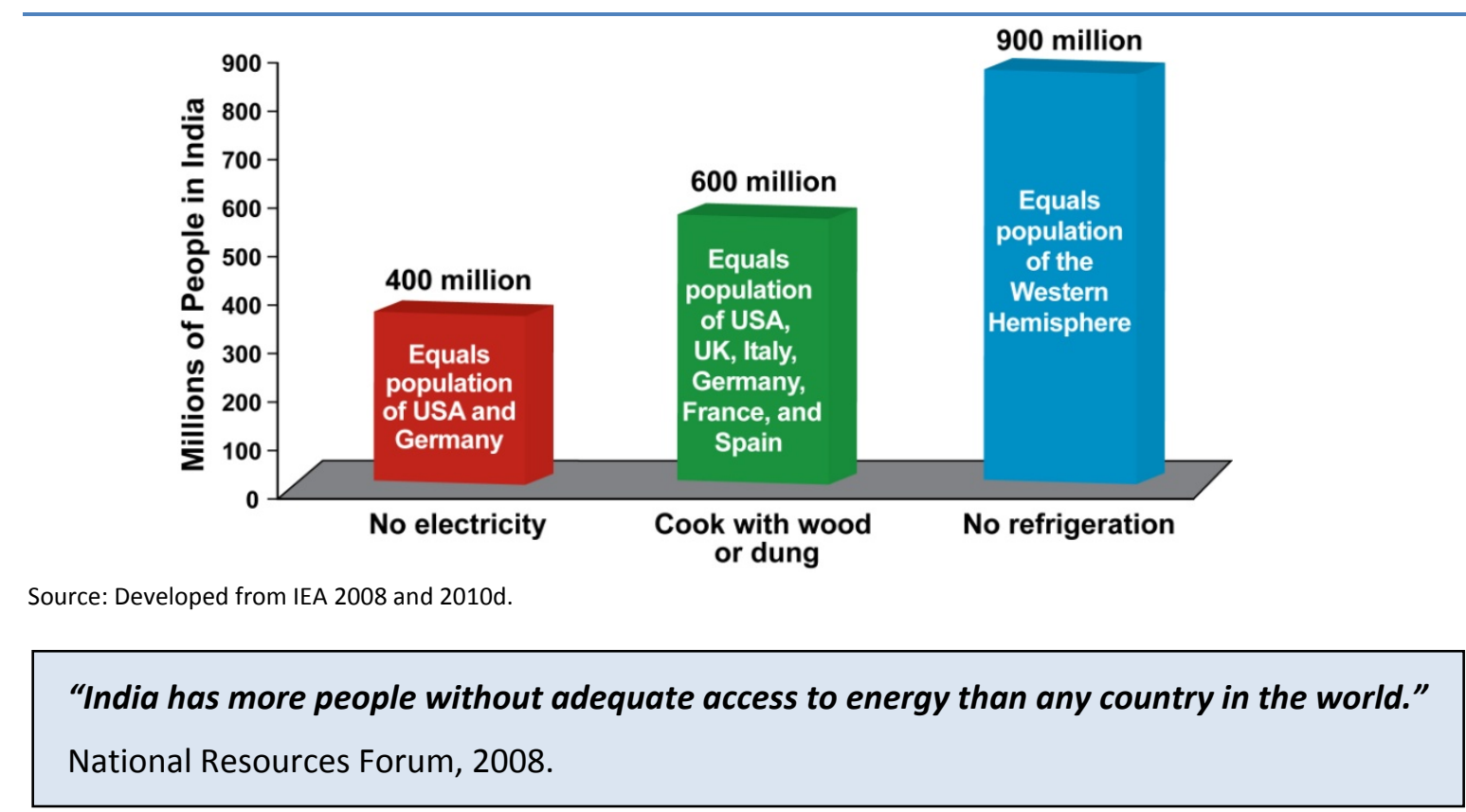

India's $11^{\text {th }}$ Five-Year Plan (2007-2012) stated that coal will continue as a major energy resource and emphasized the importance of "safe and clean technologies for environmental sustainability." Once again, the scale of coal's contribution provides a crucial perspective on its relative role in meeting energy needs. India has $18 \%$ of the world's population but only $1 \%$ of the 
world's natural gas, oil and uranium (BP, 2011; World Nuclear Association, 2010). The New Policies Scenario projects that by 2035 , India accounts for about $7 \%$ of global wind generation; in the Current Policies Scenario, wind in India accounts for about $5 \%$ of the global wind generation in 2035. India's share in the global coal-based power generation is projected to be $14 \%$ in 2035 in the New Policies Scenario.

Beyond India and South Africa, a range of other countries will also have to rely on coal to meet growing electricity demand. In the Philippines, for example, the Asian Development Bank (ADB) has approved funding to help build a coal-based power plant in the Visayas region to spur economic development and to reduce the frequent blackouts that have plagued parts of the area, including Cebu and Panay. To mitigate these problems, a $200 \mathrm{MW}$ coal-fuelled power plant will be built in Cebu. As Joe Yamagata, Deputy Director General in ADB's Private Sector Operations Department has stated: "a steady supply of power will develop the local economy, creating jobs in manufacturing, tourism and other sectors...a reliable power supply will allow hospitals schools and other public services to fully function" (ADB, 2009). 


\section{Clean coal can help meet global challenges}

All societies are concerned with the "Three E's" - energy, economy and environment. Progress in all three areas depends upon a broad number of variables but coal will continue to be a major component of the portfolio - including the challenge of meeting climate change policy goals.

Page | 22 Clean coal technologies pave the way for the broader use of coal. Coal has unique characteristics that allow it to be utilised for multiple purposes including electricity generation, steel production, and conversion to liquids and gaseous fuels.

Figure 14 The attributes of coal

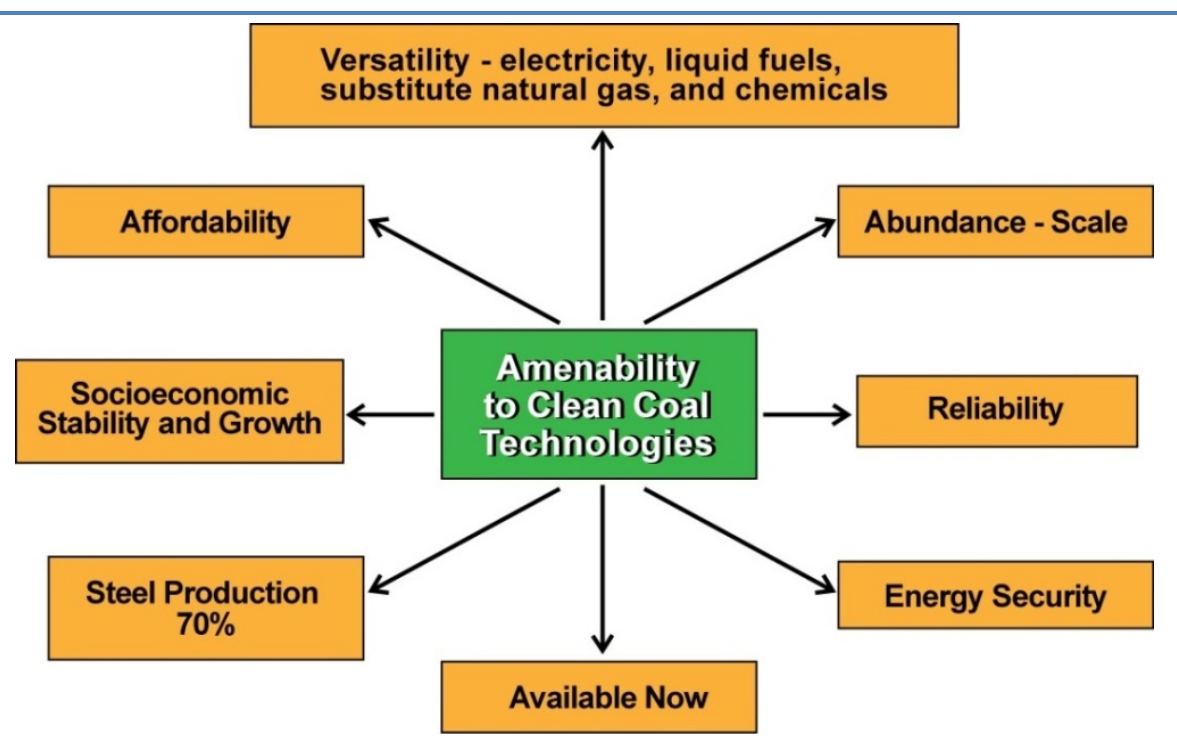

\section{A suite of $21^{\text {st }}$-century clean coal technologies can unlock the further value of coal}

Previous experience has demonstrated that clean coal technologies are successful. Since 1990, for example, the United States electric power industry has invested almost USD 100 billion to control emissions with marked success (Hewson and Stravinsky, 2008). The United States has made significant strides forward in reducing regulated emissions - particulate matter, sulphur dioxide, carbon monoxide, mercury, lead, ozone and nitrogen oxides - while substantially increasing coal-based generation and meeting the electricity needs of an expanding population in the context of a growing economy. Similar progress has been made in other countries across the world ranging from Germany to Japan to Australia.

As climate change concerns have intensified, concern about fossil fuel consumption, including coal, has increasingly shifted the focus onto alternative sources of energy and clean coal technologies as means of significantly reducing $\mathrm{CO}_{2}$ emissions.

In 2009, US Secretary of Energy Stephen Chu called for the continuing evolution of clean coal technologies into the area of CCS: "This investment is part of our commitment to advancing carbon capture and storage technologies to the point where widespread, affordable deployment can begin in 8 to 10 years. This partnership will not only help fight climate change, it will create new jobs and position the United States as a leader in carbon capture and storage technologies for years to come" (US DOE, 2010b). 
Figure 15 Clean coal technologies have reduced regulated emissions in the United States

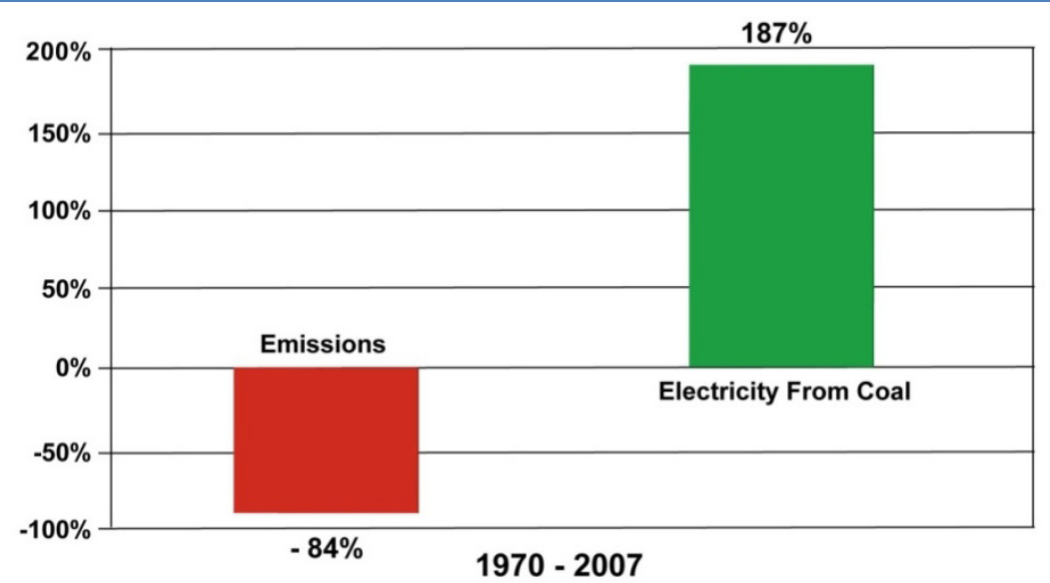

Source: Developed from EIA, 2009

Parallel initiatives have been taken in Europe (Figure 16).

Figure 16 Clean coal initiatives in Europe

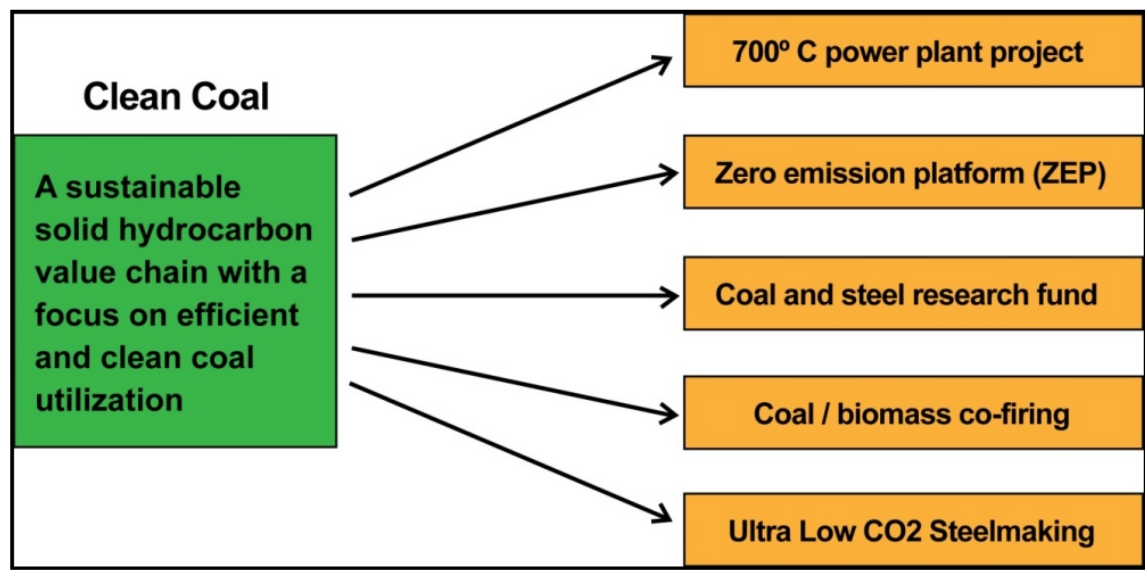

Source: Developed from IEA, 2010g.

Increasing opportunities are developing to implement two associated, continuously evolving technologies: increased energy efficiency and CCS. The synergies between these two processes will help the world address constraints in electricity, natural gas and liquid fuel supplies. Widespread deployment of clean coal technology is one means of achieving significant, long-term reductions in greenhouse-gas emissions while maintaining economic growth. As the National Academy of Sciences indicated in America's Energy Future (2009), coal-based technologies that increase efficiency and eventually employ CCS will be among the lowest cost, low-carbon alternatives for electricity generation and for energy supply (e.g. CTL). These priorities are no less evident in Europe.

"About $80 \%$ of Europe's fossil fuel reserves comprise hard coal and lignite...[coal] will continue to be particularly important for power generation...the future of coal in Europe depends on the growing use of high-efficiency power plants coupled with the widespread deployment of CCS."

IEA, 2010g. 


\section{Improved efficiency}

Increasing the efficiency of coal-fuelled power plants by one percentage point leads to a reduction in $\mathrm{CO}_{2}$ emissions of $2 \%$ to $3 \%$ (Beer, 2009) because a more efficient plant burns less fuel for the same amount of produced energy. Thus, state-of-the-art coal power plants have $\mathrm{CO}_{2}$

Page | 24 emissions up to $40 \%$ lower than the average for all coal plants. Ensuring that all new coal-fired plants are constructed using the most efficient technologies applicable to local conditions, combined with the replacement of existing, highly inefficient coal-fuelled plants, can deliver significant global $\mathrm{CO}_{2}$ reductions and reduce $\mathrm{CO}_{2}$ emissions from coal by almost $25 \%$. This would represent a $6 \%$ reduction in global $\mathrm{CO}_{2}$ emissions $(\mathrm{CIAB}, 2009)$. Several countries have taken the lead. Today's best available technology allows efficiency up to $46 \%$ for hard coal plants and $43 \%$ for lignite-fired plants (IEA, 2010a).

In Europe, the current Seventh Framework Programme (FP7) seeks to increase efficiency to over $50 \%$ through further research and development and better integration of components. In both Denmark and Japan, coal-fuelled power generation is operated with a total efficiency rate of $40 \%$ or more, the highest national rates in the world (IEA, 2010a). In Germany, there are $8230 \mathrm{MW}$ power capacity on the basis of hard coal, with an efficiency rate of $46 \%$ under construction. Furthermore, $2760 \mathrm{MW}$ of power capacity on the basis of lignite are under construction, with an efficiency rate of more than $43 \%$. Thus, a total of $11000 \mathrm{MW}$ of highly efficient, coal-based power capacity is under construction in Germany and scheduled to begin operation between 2011 and 2013.

"China has since become the major world market for advanced coal-fired power plants with high-specification emission control systems."

IEA, 2009f.

One of the best examples of this new advanced generation is in China and, in fact, is the world's most efficient coal-based power plant. Shanghai Waigaiqiao \#3, which has two $1000 \mathrm{MW}$ coalbased units, provides one-fourth of Shanghai's electricity and uses 282 grams of coal per kWh compared to world average of 316 grams/kWh. Its peak efficiency rate is $46.3 \%$ (Mao, 2009).

But perhaps the most important efficiency effort in the world is China's Large Substitute for Small (LLS) programme. Beginning in early 2007, the Chinese government adopted strong steps to phase out inefficient coal-generating units by creating and implementing this programme. LSS was designed to decommission about $50 \%$ of existing inefficient small units by 2010 . Over $114000 \mathrm{MW}$ of small units will be decommissioned and replaced with $112000 \mathrm{MW}$ of supercritical and ultra-supercritical generating capacity. This programme has been extremely successful and has already resulted in significant reduction in GHG and other pollutant emissions, lower fuel consumption and an impressive improvement in energy efficiency (ADB, 2008).

\section{Carbon capture and storage (CCS)}

In 2008, the IEA identified CCS for power generation as "the single most important new technology for $\mathrm{CO}_{2}$ savings." In 2010, the IEA concluded that the high costs of alternative sources of electricity "demonstrate the importance of the availability of CCS as an option for mitigating $\mathrm{CO}_{2}$ emissions." Researchers at the Massachusetts Institute of Technology (MIT, 2007) have stated that $\mathrm{CCS}$ "is the critical enabling technology that would reduce $\mathrm{CO}_{2}$ emissions significantly 
while also allowing coal to meet the world's pressing energy needs." The Clean Air Task Force (2009) has been even more direct: "No credible technical body has found that adequate $\mathrm{CO}_{2}$ emissions reductions are possible without widespread use of CCS. Given this widespread technical support for CCS, policy leaders around the world have stressed the importance of developing and implementing CCS programmes:

- In June 2010, the G8 summit concluded: "We encourage the IEA to develop work on an International Platform for low-carbon technologies, in order to accelerate their development and deployment. Carbon capture and storage (CCS) can play an important role in transitioning to a low-carbon emitting economy."

- In August 2010, President Obama's Interagency Task Force concluded: "CCS can greatly reduce $\mathrm{CO}_{2}$ emissions from new and existing coal- and gas-fired power plants [and] play an important role in achieving global greenhouse-gas reduction goals."

Figure 17 shows the characteristics of 80 of the largest active or planned CCS facilities around the world. As these data indicate, power generation accounts for over half of the projects.

Figure 17 Characteristics of large-scale integrated CCS projects $(N=80)$

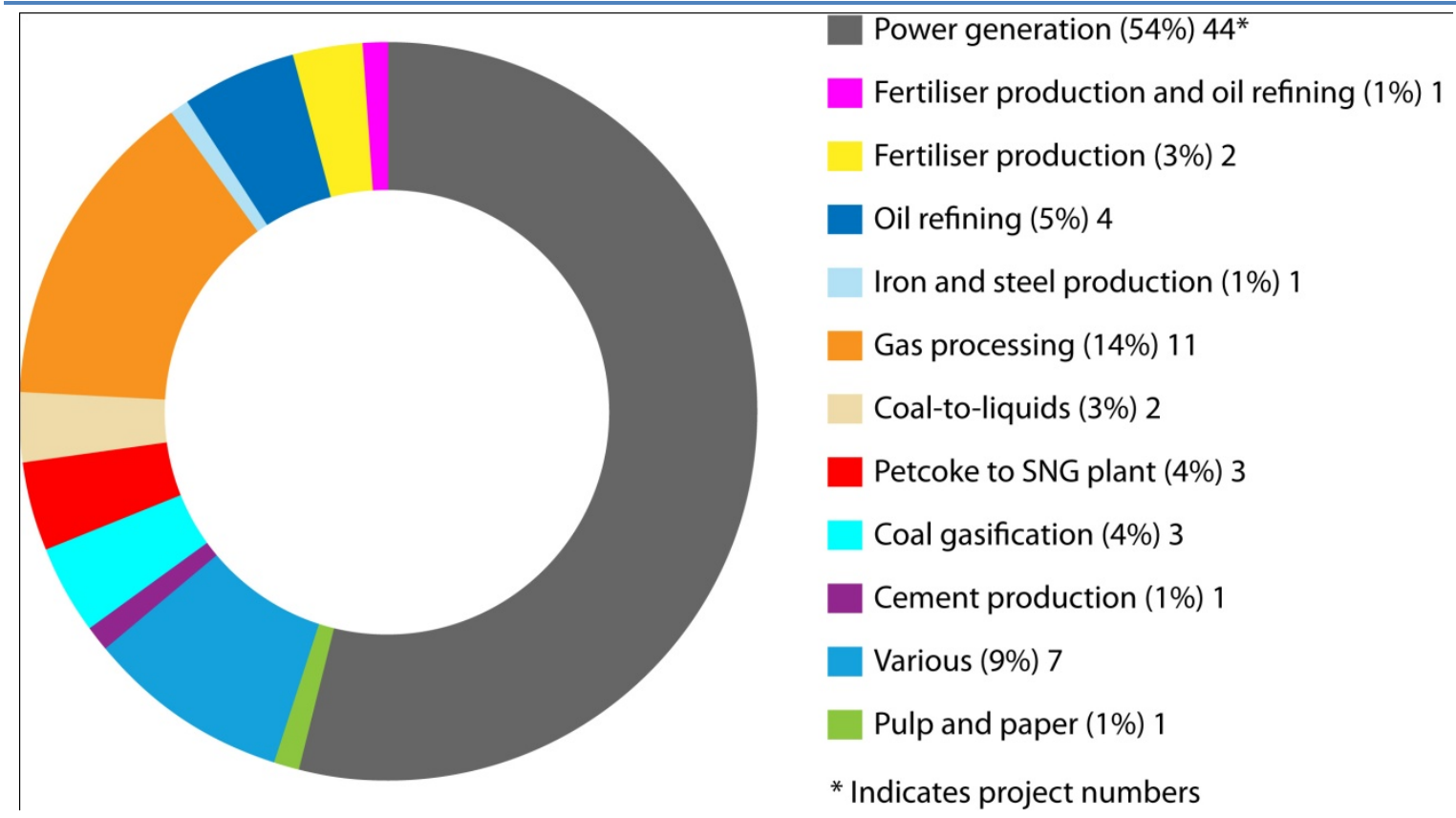

Source: Global CCS Institute, 2010.

To further enhance the feasibility of broad-scale deployment of CCS in coal-based plants, research is being undertaken around the world to reduce the amount of energy it takes to capture and compress the $\mathrm{CO}_{2}$ for transport and storage. Research at the Massachusetts Institute of Technology, for example, is just one of a number of projects worldwide that are developing technologies that will reduce the energy penalty (MIT, 2009). Further, efficiency in power production can be increased to mitigate this penalty. In this context, R\&D on efficient coal-fired technologies is important and policy to promote this $R \& D$ is necessary. 


\section{Beneficial re-use: socio-economic and environmental benefits of the utilisation of captured $\mathrm{CO}_{2}$}

At least some of the captured $\mathrm{CO}_{2}$ be can utilised in manufacturing. The use of $\mathrm{CO}_{2}$ in enhanced oil recovery will be the most beneficial significant aspect of the CCS process. The security and sustainability of the world's energy system has been a perennial concern since World War II (National Academy of Sciences, 2009). Experience over the past three decades has demonstrated that the supply chains for petroleum are relatively fragile and there are at least some signs that the world is approaching peak conventional oil production.

An example of how coal-based power generation with CCS can significantly affect oil supply can be drawn from a scenario developed by the US National Energy Technology Laboratory (NETL) regarding the opportunities to increase supplies of oil through $\mathrm{CO}_{2}$-EOR. NETL (2009) has indicated that about 2 million barrels per day $(\mathrm{mb} / \mathrm{d})$ of liquid fuels can be obtained through $\mathrm{CO}_{2}$-EOR within the continental United States. Such production would have a dramatic impact on US liquid fuel supplies.

"Enhanced oil recovery with carbon dioxide is a win-win-win...CO $\mathrm{CO}_{2}-\mathrm{EOR}$ has a substantial immediate to long-term role to play in both increasing domestic oil production... and in sequestering $\mathrm{CO}_{2}$ underground."

Natural Resources Defense Council, 2008.

Thus, the potential of EOR to simultaneously contribute to energy supply and $\mathrm{CO}_{2}$ emissions reductions in the United States is substantial; the 2009 NETL analysis suggests three major benefits would accrue from using integrated next-generation $\mathrm{CO}_{2}$ storage and EOR:

- Roughly 119 billion barrels of additional technically recoverable domestic oil would be available and up to 70 billion barrels would be economically recoverable under reasonable scenarios.

- $\mathrm{CO}_{2}$-EOR technology would create a demand for up to $13 \mathrm{Gt}$ of captured $\mathrm{CO}_{2}$ - roughly equivalent to captured $\mathrm{CO}_{2}$ emissions from $70 \mathrm{GW}$ of coal-based power plants over a 30-year life span.

- The additional oil produced with injection of captured $\mathrm{CO}_{2}$ emissions is $50 \%$ to $80 \%$ "carbonfree," after accounting for the difference between the carbon content in the incremental oil produced by EOR and the volume of $\mathrm{CO}_{2}$ stored in the reservoir.

Based on the NETL findings, the $\mathrm{CO}_{2}$ demand from EOR in the United States alone could equal the $\mathrm{CO}_{2}$ captured from consuming over $360 \mathrm{Mt}$ of coal per year.

The production of cement will initially be one of the most extensive uses for captured $\mathrm{CO}_{2}$ in manufacturing. Cement is mostly comprised of calcium silicates and requires heating limestone to over $1400^{\circ} \mathrm{C}$. In the United States, cement production is the third-largest source of GHG emissions (Scientific American, 2008). Technologies are emerging that could turn cement from a source of greenhouse gas to a carbon-neutral process. Calera Corporation in California has developed a process that would allow for the sequestering of half a tonne of $\mathrm{CO}_{2}$ for every tonne of cement produced. This process is similar to marine cement, which is produced by coral when making their shells. The process fundamentally turns $\mathrm{CO}_{2}$ into carbonic acid and that product is made into carbonate. The process is at least carbon neutral. The US DOE (2010a) has funded research with Calera to demonstrate the process is viable at a significant scale. 
The US DOE is also pursuing other means of beneficial $\mathrm{CO}_{2}$ use. Projects include development of:

- mineralisation technology to transform $\mathrm{CO}_{2}$ into solid carbonate and/or bicarbonate materials;

- an integrated system designed to produce liquid biocrude fuel from microalgae cultivated with captured $\mathrm{CO}_{2}$; and (c) a process for converting waste $\mathrm{CO}_{2}$ into a number of polycarbonate products (plastics) for use in the packaging industry. While these are pilot projects at a relatively small scale, it is clear that emerging technologies are being developed to utilise $\mathrm{CO}_{2}$ captured, thereby reducing total emissions. 


\section{Coal's attributes are far-ranging}

A number of characteristics are relevant to coal's past, present and future role in the global energy system.

Page | 28

\section{Abundance and accessibility}

Coal is the world's most abundant and widely distributed fossil fuel, accounting for $64 \%$ of global economically recoverable fossil fuel resources compared to $19 \%$ for oil and $17 \%$ of natural gas.

The amount of proven recoverable coal reserves is enormous and exceeds one trillion tonnes. Coal is distributed across every continent and every region of the world. The Western Hemisphere itself has over 300 billion tonnes of coal (Table 3 ).

Table 3 Proven recoverable coal reserves across geographic and political regions*

\begin{tabular}{l|r|r|r}
\hline Region & Hard Coal & Brown Coal & Total Coal \\
\hline OECD Europe & 18322 & 54820 & 73142 \\
\hline OECD North America & 218818 & 35614 & 254432 \\
\hline OECD Pacific & 41477 & 38033 & 79510 \\
\hline Russia & 69946 & 91607 & 161553 \\
\hline China & 167000 & 25000 & 192000 \\
\hline India & 95399 & 467 & 95866 \\
\hline Rest of Asia & 10283 & 10664 & 20947 \\
\hline South America & 19769 & 124 & 19893 \\
\hline Africa / Middle East & 52846 & 202 & 53048 \\
\hline Total & 736112 & $\mathbf{2 8 3 1 8 4}$ & $\mathbf{1 0 1 9 2 9 6}$ \\
\hline
\end{tabular}

* In million tonnes.

Sources: Developed from IEA, 2009b, 2009d and 2009e.

The size of the coal resource is so substantial that it extends energy planning horizons into the next century. The National Academy of Sciences (2009) has summed up the situation regarding the United States alone:

"U.S. recoverable reserves of coal are well over 200 times the current annual production of 1 billion tonnes, and additional identified resources are much larger. Thus the coal resource base is unlikely to constrain coal use for many decades to come."

National Academy of Sciences, 2009.

\section{Secure energy}

The global distribution of the coal resource is such that it has provided and will continue to provide energy security to entire political arenas. Europe, for example, has at least 73 billion tonnes of coal - an "in-the-ground" resource that not only provides $18 \%$ of Europe's energy but is a readily available supply as clean coal technologies pave the way to broader acceptance of coal utilisation for electricity and coal conversion projects. The widespread physical distribution of 
coal provides a significant measure of energy security to many countries across the globe. The significant socio-economic impact of both the oil embargo and revolution in Iran in the 1970s exemplified the issue.

\section{Reliability}

Coal's abundance and distribution, coupled with its relatively low and stable price history, set the stage for a reliable supply of energy. In the area of electricity, for example, coal-based generation is one of the first sources to be dispatched throughout the electric grid. Coal's reliability characteristics make it an attractive baseload fuel. Consistently, the amount of electricity generated from coal significantly exceeds coal's relative capacity compared to most other fuels. In 2008 , for example, coal accounted for $31 \%$ of global generation capacity but produced $41 \%$ of electricity.

For highly developed economies such as Western Europe and the United States, the reliability of electric power is essential. The costs of electricity supply interruptions per lost megawatt hour are several orders of magnitude larger than the cost of base load or peak electricity supply costs. The ability of a fuel to provide uninterrupted energy for power generation is highly valuable in modern societies.

\section{Affordability}

Relatively low and stable prices have contributed to coal's rising market share in recent years. This low-cost structure for the coal industry provides an important buffer for world energy markets. For example, if coal's market share had stayed at 23\% from 1998 to 2007, over nine million additional barrels of oil equivalent per day would have been required by 2007 . Under such a scenario, the price spike for oil and natural gas during 2008 likely would have been considerably higher.

Recent trends in world energy consumption and prices suggest that coal is playing a pivotal role in keeping energy affordable. Affordability and price stability are important reasons developing nations are turning to coal-based generation. Consider, for example, the position of China a country which is projected to build between $500 \mathrm{GW}$ and $1000 \mathrm{GW}$ of new coal capacity by 2035. Supercritical plants are one of the most affordable sources of power generation in China (IEA, 2010a).

Figure 18 Levelised cost of electricity (LCOE) in China, an example of a developing country

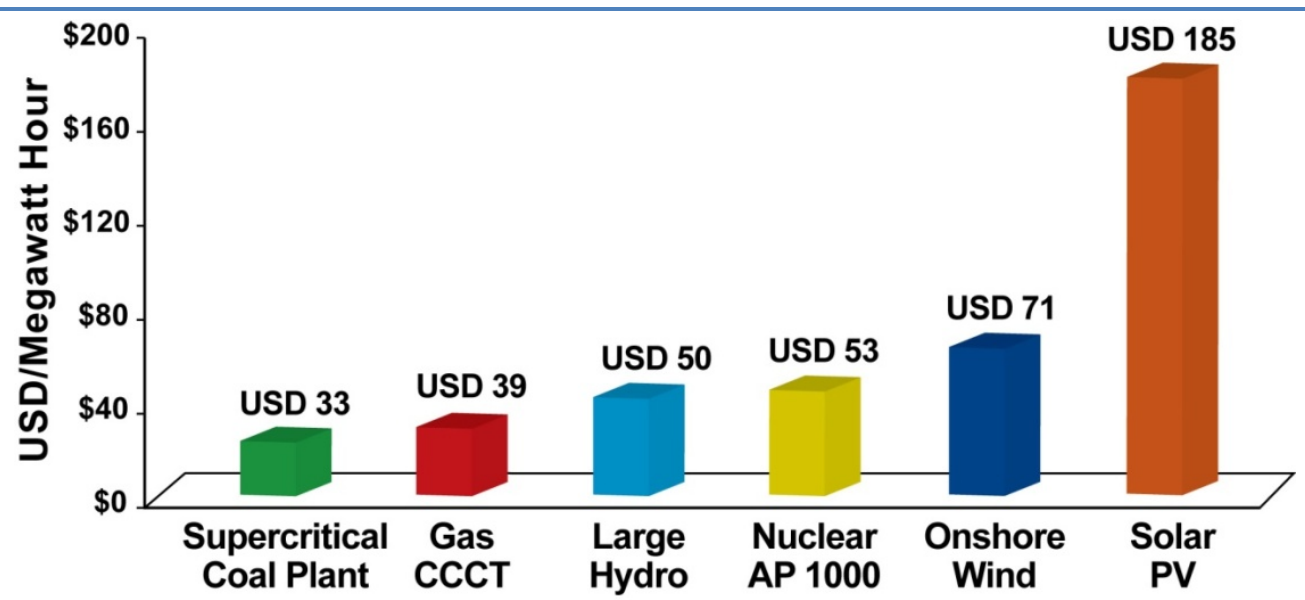

Source: IEA, 2010c. 
At the global level, the IEA's 2010 (c) literature review of electricity generation costs broadly verified the relative lower cost of coal generation. This analysis focused on levelised cost of electricity generation - the minimum price of electricity at which a technology generates enough revenue to pay all of the utilities' costs, including a sufficient return to investors.

\section{Page | 30 Versatility}

Coal conversion can produce a wide range of products, including liquid fuels (CTL), substitute natural gas (SNG) and chemicals (CTC). In the United States, the National Academy of Sciences (2009) concluded that CTL with CCS could increase the nation's oil supply in 2035 by $3 \mathrm{mb} / \mathrm{d}$. China has already initiated development of massive coal conversion projects and the scope of their emerging projects is especially informative, suggesting that the goal is to produce an additional 1.2 billion tonnes of coal over the next decade and to utilise that coal in various conversion projects. Much of the coal will come from the new mines in Xinjiang Province, a region where more than one billion tonnes of additional coal production is planned by 2020 (Jiachun, 2009).

Figure 19 China's plan of converting coal in Xinjiang Province by 2020

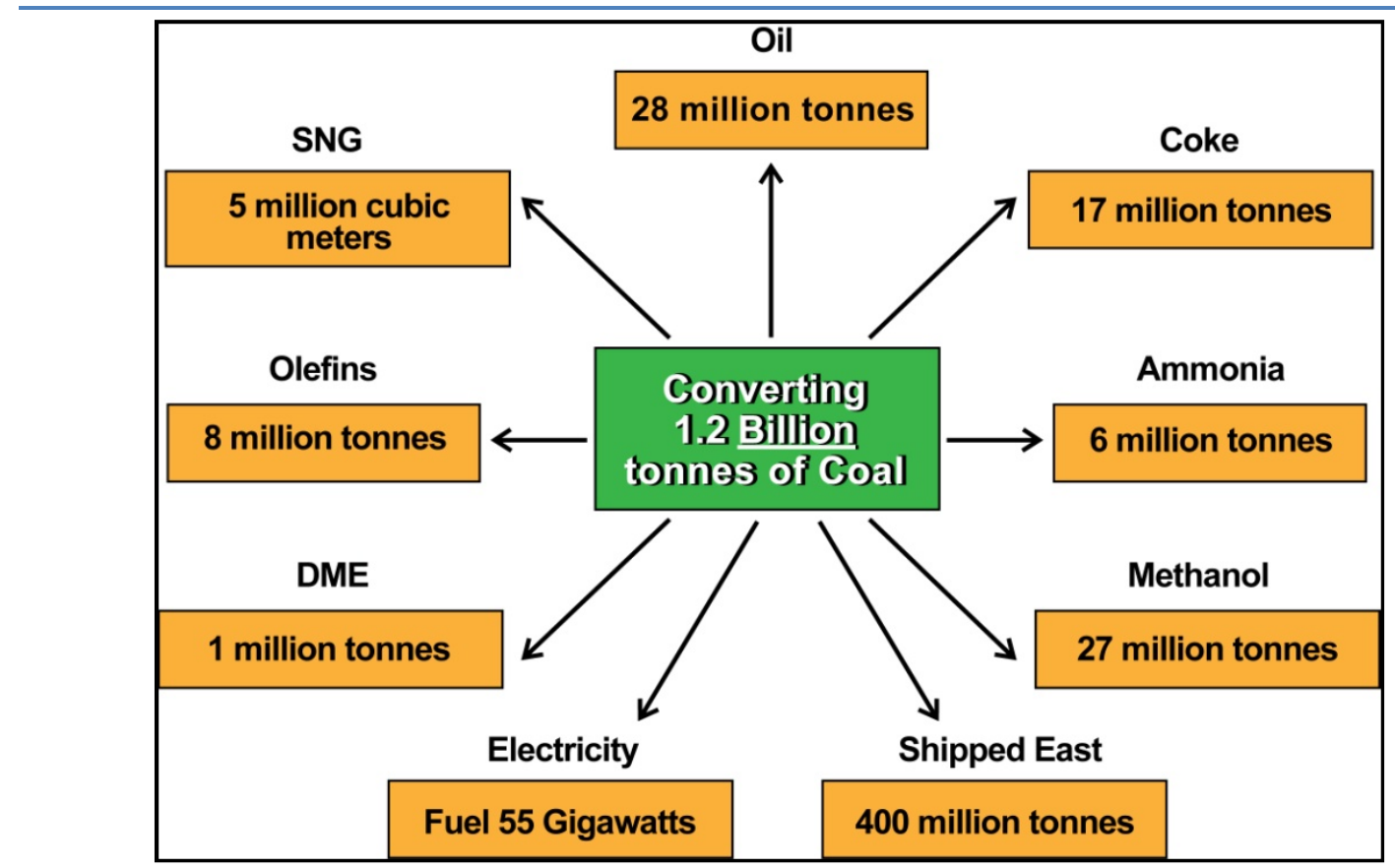

Source: Developed from Jiachun, 2010.

China has made a national commitment to coal conversion. There are dozens of projects in operation, under construction or planned throughout the country (Sun, 2010). Some examples demonstrate the scale of these projects:

- Shenhua Group Corporation initiated the world's first commercial direct CTL plant in Inner Mongolia in 2002. Eventually, the Shenhua plant is expected to produce about $1.1 \mathrm{Mt}$ of oil products and chemicals per year based on the consumption of $3.45 \mathrm{Mt}$ of coal.

- Yitai Group constructed an indirect CTL plant in 2008 that will ultimately produce about 110000 metric tonnes of diesel, 38000 metric tonnes of naphtha and 12000 metric tonnes of LPG each year. 
- Datang Group is developing two coal-to-substitute natural gas projects in Northeastern China. One of the projects is designed to produce 4 billion cubic meters $(\mathrm{bcm})$ of SNG each year, which will be mainly transmitted through a pipeline.

- Shenhua finished construction of the world's largest coal-to-olefins (СTO) plant in Baotou, Inner Mongolia in June 2010. This plant is designed to produce nearly $1.8 \mathrm{Mt}$ of methanol for approximately 600000 tonnes of polyethylene and polypropylene per year. Olefin is an unsaturated chemical compound containing at least one carbon-to-carbon double bond.

In addition to traditional coal-fired power generation, integrated gasification combined cycle (IGCC), such as China's GreenGen Project, is becoming increasingly important. Huaneng Group, the largest power company in China, is leading development of GreenGen technology for research and development demonstration (RD\&D) of integrated coal gasification, hydrogen production, hydrogen power generation and $\mathrm{CO}_{2}$ sequestration system. A $2 \times 400 \mathrm{MW}$ IGCC plant as the second step of GreenGen will be constructed in Tianjin. The geographic range, diversity and scale of these projects indicate the extent of the commitment that China is making to coal conversion.

\section{Steel, cement and related construction materials}

Steel provides the backbone to modern civilisation and coal is an essential component of steel production. More than two-thirds of steel production utilises metallurgical coal (coking coal). Much of the remaining one-third is produced by recycling scrap steel in electric arc furnaces where the power used is often provided by coal.

By 2030 , the urban population of the world will increase to $60 \%$ of the global population and by 2050 it will be upwards of $70 \%$. This urbanisation will make huge demands on infrastructure and require increasing amounts of steel - which, in turn, requires the use of more coal.

Figure 20 The rise of the Chinese metropolis: the steel required to build cities alone

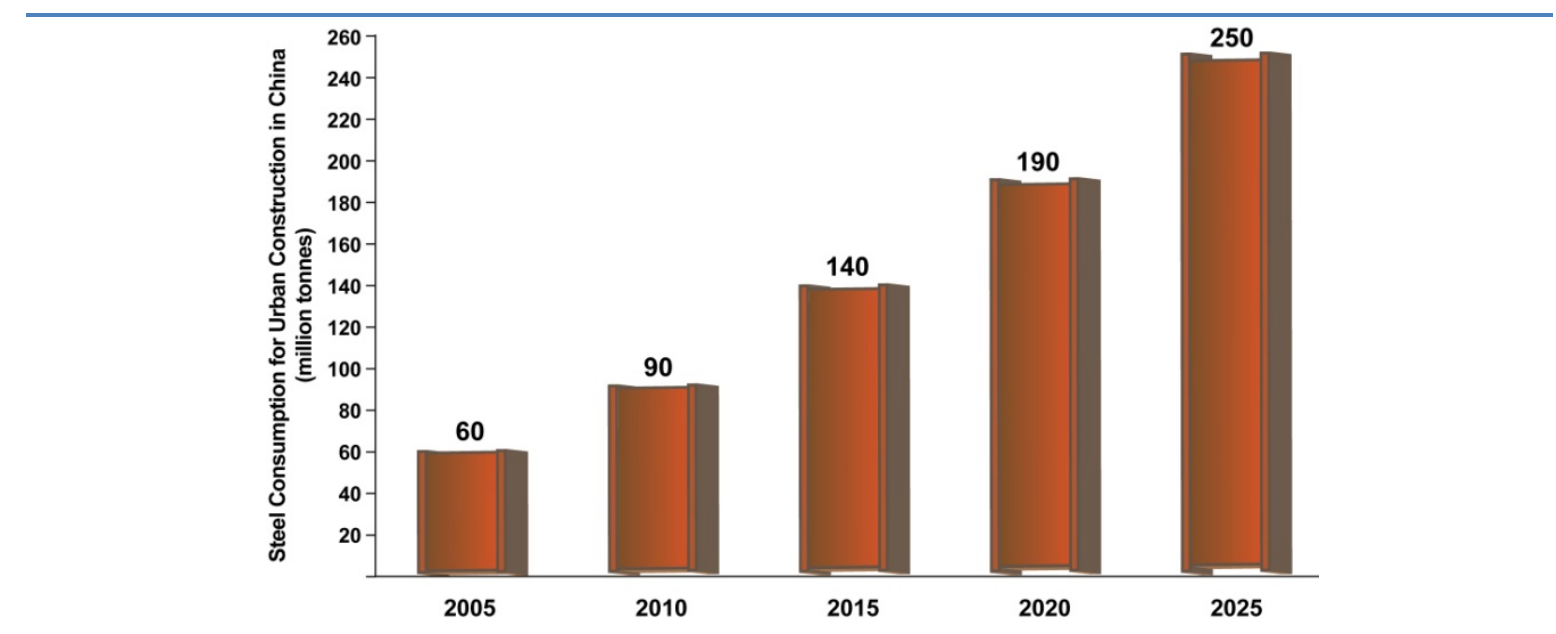

Source: Developed from McKinsey and Company, 2008.

By 2030, one billion Chinese will live in cities - the result of the largest internal migration in history.

Importantly, the speed and scale of urbanisation today are far greater than in the past. This implies a variety of new challenges for cities in poorer countries. They will need to build new urban infrastructure - houses, power, water, sanitation, roads, and commercial and production 
facilities - more rapidly than cities anywhere during the first wave of urbanisation (from 1800 to 2000). Research by McKinsey and Company (2008) has indicated that the height of buildings has a substantial impact on demand for steel - and skyscrapers demand most of all. As an example, a building of 45 floors requires about 128 kilograms $(\mathrm{kg})$ of steel per square meter compared to only $55 \mathrm{~kg}$ per square meter in a ten-floor building. China alone may build 50000 skyscrapers

Page | 32 over the next 20 years - the equivalent of ten New York cities. Given the massive urban development that will take place over the next 40 years, the demand for steel will increase with a corresponding increase in the demand for coal.

\section{Socio-economic benefits}

A broad implementation of clean coal technologies will have positive impacts for virtually every nation. For example, the world has approximately $1000 \mathrm{GW}$ of traditional, coal-fuelled power plants. Research by Management Information Services, Inc. (2010) in the United States has indicated that replacing these older plants will create USD 4.3 trillion in economic benefits and 21 million construction jobs.

"These new technologies not only will help fight climate change, they will create jobs now."

Steven Chu, US Secretary of Energy, (US DOE, 2010b).

Research conducted by BBC Consulting for the American Federation of Labor and Congress of Industrial Organizations AFL-CIO (2009) has clearly laid out the potential benefits in terms of jobs and income.

Table 4 Economic benefits from operation and maintenance of $360 \mathrm{GW}$ of advanced coal-based generation facilities with CCS

\begin{tabular}{l|c|c|c}
\hline Measure & Direct benefit & Indirect benefit & Total benefit \\
\hline Permanent jobs & 176400 & 669600 & 846000 \\
\hline Salaries (USD) & 22 billion & 35 billion & 57 billion \\
\hline
\end{tabular}

Source: Developed from AFL-CIO/ BBC Research and Consulting, 2009. 


\section{Conclusion}

Coal holds significant potential as an energy source to aid global efforts to eradicate poverty, expand economic growth and meet climate change goals. But coal is not without its challenges. Clean coal technologies, especially high efficiency power generation and CCS, are the pathways to unlocking the extensive reserves of coal widely dispersed across the globe. Given the attributes of coal and the contribution of advanced technologies, the road leading from the Copenhagen Accord can be outlined as follows:

- eliminate energy poverty as a first-order priority;

- create access to energy for everyone, everywhere by 2050;

- advance all energy forms for long-term, sustainable access; and

- commercialise and deploy advanced clean technologies to eventually reach near-zero emissions from coal and natural gas power plants.

Dramatically reducing $\mathrm{CO}_{2}$ emissions is a major challenge, but it is tractable through continuously evolving technologies. The parallel question is whether the world will actually deliver on the second promise out of Copenhagen - eradication of poverty and energy deprivation. Current IEA projections indicate 1.2 billion people will still be without electricity in 2030. Just as importantly, perhaps as many as two billion others will have only sporadic and limited access to power (IEA, 2011b). As the data presented here demonstrate, clean coal presents a unique opportunity for the world to meet both economic and environmental goals affordably, reliably and sustainably. 


\section{References}

ADB (Asian Development Bank) (2008), Implementing Energy Efficiency Programmes in China's Power Generation Sector: Case Study of a Recent Policy Initiative, Mandaluyong City, Philippines.

ADB (2009), ADB Approves Loan to Boost Power Supply in Central Philippines, 23 December, available at http://beta.adb.org/news/adb-approves-loan-boost-power-supply-central-philippines.

AFL-CIO (American Federation of Labor and Congress of Industrial Organizations) (2009), Employment and Other Economic Benefits from Advanced Coal Electric Generation with Carbon Capture and Storage, February, research conducted by BBC Research and Consulting.

Beer, J. (2009), Higher Efficiency Power Generation Reduces Emissions, Massachusetts Institute of Technology (MIT), available at http://web.mit.edu/mitei/docs/reports/beer-emissions.pdf.

Biello, D. (2008), “Cement from $\mathrm{CO}_{2}$ : A Concrete Cure for Global Warming?”, in Scientific American, available at www.scientificamerican.com/article.cfm?id=cement-from-carbon-dioxide, published 7 August.

Boston Consulting Group (2010), The Internet's New Billion, Sao Paulo, Brazil, available at www.bcg.com/documents/file58645.pdf, published August.

BP (British Petroleum) (2010), Statistical Review of World Energy June, London.

CARE (2010), Ending Poverty: Why Empower Women and Girls? CARE available at http://womensrights.change.org/blog/view/empower_women_end_poverty_get_moving, published 15 February.

CIA World Fact Book (2010), Country Profiles, Washington DC, available at www.cia.gov/library/publications/the-world-factbook/docs/profileguide.html.

Clean Air Task Force (CATF) (2009), Coal Without Carbon: An Investment Plan for Federal Action, Boston, MA, available at www.catf.us/resources/publications/view/101.

Davidson O., N. Hirst and W. Moomaw (2010), Recommendations to The World Bank Group on Lending to South Africa for Eskom Investment Support Project that Includes a Large Coal Burning Power Station at Medupi, available at http://siteresources.worldbank.org/INTENERGY2/Resources/ExpertPanelFinalReport.pdf, published 18 February.

EIA (Energy Information Administration) (2009), International Energy Outlook 2009, US Department of Energy (US DOE), Washington, DC, available at www.eia.gov/oiaf/archive/ieo09/index.html.

EIA (2010a), International Energy Outlook 2010. US Department of Energy. Washington, DC, available at www.eia.doe.gov/oiaf/ieo.

EIA (2010b), Annual Energy Outlook 2009. US Department of Energy. Washington, DC, available at www.eia.doe.gov/oiaf/aeo/supplement.

Global CCS Institute (2010), The Status of CCS Projects Interim Report 2010, Canberra, Australia, available at www.globalccsinstitute.com/resources/publications/status-ccs-projects-interim-report.

Global Energy Network Institute (2002), Electricity for All: Targets, Timetables, and Instruments. San Diego, California, available at www.geni.org/globalenergy/library/media_coverage/electricite-defrance/electricity-for-all--targets-timetables-instuments.shtml, published October, 2002.

Gordham, P. (2010), "Why Coal is the Best Way to Power South Africa's Growth", The Washington Post, available at www.washingtonnepost.com/wpdyn/content/article/2010/03/21/AR2010032101711.html, published 22 March.

Hewson T. and B. Stravinsky (2008), Air Pollution Control Investment by Coal-Fired Power Plants, Energy Ventures Analysts, Pittsburgh, Pennsylvania, United States.

IEA (International Energy Agency) (2002) World Energy Outlook 2002, OECD/IEA, Paris. 
IEA (2007), World Energy Outlook 2007, OECD/IEA, Paris.

IEA (2009a), World Energy Outlook 2009, OECD/IEA, Paris.

IEA (2009b), Coal Information 2009, OECD/IEA, Paris.

IEA (2009c), Gadgets and Gigawatts, OECD/IEA, Paris.

IEA (2009d), Future Coal Supply Prospects, OECD/IEA, Paris, published in March.

IEA (2009e), Underground Coal Gasification, IEA Clean Coal Centre, OECD/IEA, Paris, published in July.

IEA (2009f), Cleaner Coal in China, OECD/IEA, Paris.

IEA (2010a), Energy Technology Perspectives 2010, OECD/IEA, Paris.

IEA (2010b), Energy Poverty: How to Make Modern Energy Access Universal? OECD/IEA, Paris.

IEA (2010c), Projected Costs of Generating Electricity, OECD/IEA, Paris.

IEA (2010d), Access to Electricity, OECD/IEA, Paris, available at www.iea.org/weo/database_electricity/electricity_access_database.htm.

IEA (2010e), World Energy Outlook 2010, OECD/IEA, Paris.

IEA (2010g), Prospects for Coal, CCTs and CCs in the European Union, OECD/IEA, Paris.

IEA (2010 h), Electricity Information, OECD/IEA, Paris,

IEA (2011a), Energy Poverty: The Missing Millennium Development Goal? OECD/IEA, Paris, available at www.iea.org/index_info.asp?id=1847.

IEA (2011b), World Energy Outlook 2011, OECD/IEA, Paris.

Jiachun, W. (2010), Xinjiang's Coal Industry in the $21^{\text {st }}$ Century, available at http://en.cnki.com.cn/Journal_en/B-B021-ZGME-2009-12.htm.

Mao, J. (2009), Supercritical Units in China, Technical Conference on Coal Utilization, Tampa, FLA, May.

Management Information Services, Inc. (MISI) (2010), Economic Impact of Construction Advanced Coal Plants, Washington, DC.

MIT (Massachusetts Institute of Technology) (2009), The Future of Coal, Cambridge, MA, available at web.mit.edu/coal/.

McKinsey and Company Global Institute (2008), Preparing for China's Urban Billion, available at www.mckinsey.com/mgi/publications/china_urban_summary_of_findings.as ppublished March 2009).

National Academy of Sciences (NAS) (2009), America's Energy Future: Technology and Transformation, Washington, DC.

National Resources Defense Council (NRDC) (2008), Tapping into Stranded Domestic Oil: Enhanced Oil Recovery with Carbon Dioxide is a Win-Win-Win, NY, NY, available at www.nrdc.org/energy/eor.pdf, published July.

National Resources Forum, (2006) Vol. 30, No.1, p. 14 , March 2006.

The New York Times, May 4, (1930), Figure 2.1.

Sun, Q. (2010), Coal Conversion Process, State-of-the-art paper prepared at US-China Clean Coal Center, West Virginia University, Morgantown, WV, September.

UNICEF (2009), 20 Years - The Convention on the Rights of the Child. UNICEF, New York, available at www.unicef.org/rightsite/.

United Nations Framework Convention on Climate Change (UNFCCC 2009), Copenhagen Accord, Bonn, Germany, available at http://unfccc.int/resource/docs/2009/cop15/eng/l07.pdf, published 18 December. 
United Nations (n.d.), Population Information Network, New York, available at www.un.org/popin/data.html.

US DOE (US Department of Energy) (2010a), Innovative Concepts for Beneficial Reuse of Carbon Dioxide. Washington, DC, available at http://fossil.energy.gov/recovery/projects/beneficial_reuse.html.

US DOE (2010b), Secretary Chu Announces Carbon Capture and Storage Simulation Initiative, Washington, DC, available at www.energy.gov/9460.htm, published 8 September).

US National Academy of Engineering (NAE) (2004), Greatest Engineering Achievements of the 20th Century, available at www.greatachievements.org/?id=2988.

World Bank (2008a), The Welfare Impact of Rural Electrification: A Reassessment of the Costs and Benefits, Independent Evaluation Group, Washington, DC, available at http://Inweb90.worldbank.org/oed/oeddoclib.nsf/DocUNIDViewForJavaSearch/EDCCC33082FF8BEE85 2574EF006E5539/\$file/rural_elec_full_eval.pdf.

World Bank (2008b), China Urban Development Quarterly, New York, available at http://wbi.worldbank.org/wbi/Data/wbi/wbicms/files/drupalacquia/wbi/ChinaUrbanDevtQtrly\%28Issue5\%29-English.pdf.

World Bank (2009), World Development Indicators 2009, Washington, DC.

World Bank (2010a), The Welfare Impact of Rural Electrification, Washington, DC, available at http://siteresources.worldbank.org/EXTRURELECT/Resources/exec_summary.pdf.

World Bank (2010b), World Development Indicators 2010, Washington, DC.

World Nuclear Association (WNA) (2010), London, UK, available at www.worldnuclear.org/about/contact.html.

World Steel Association (WSA) (2010), Steel in Figures, Brussels, available at www.worldsteel.org. 


\section{iea}

\section{International Energy Agency}
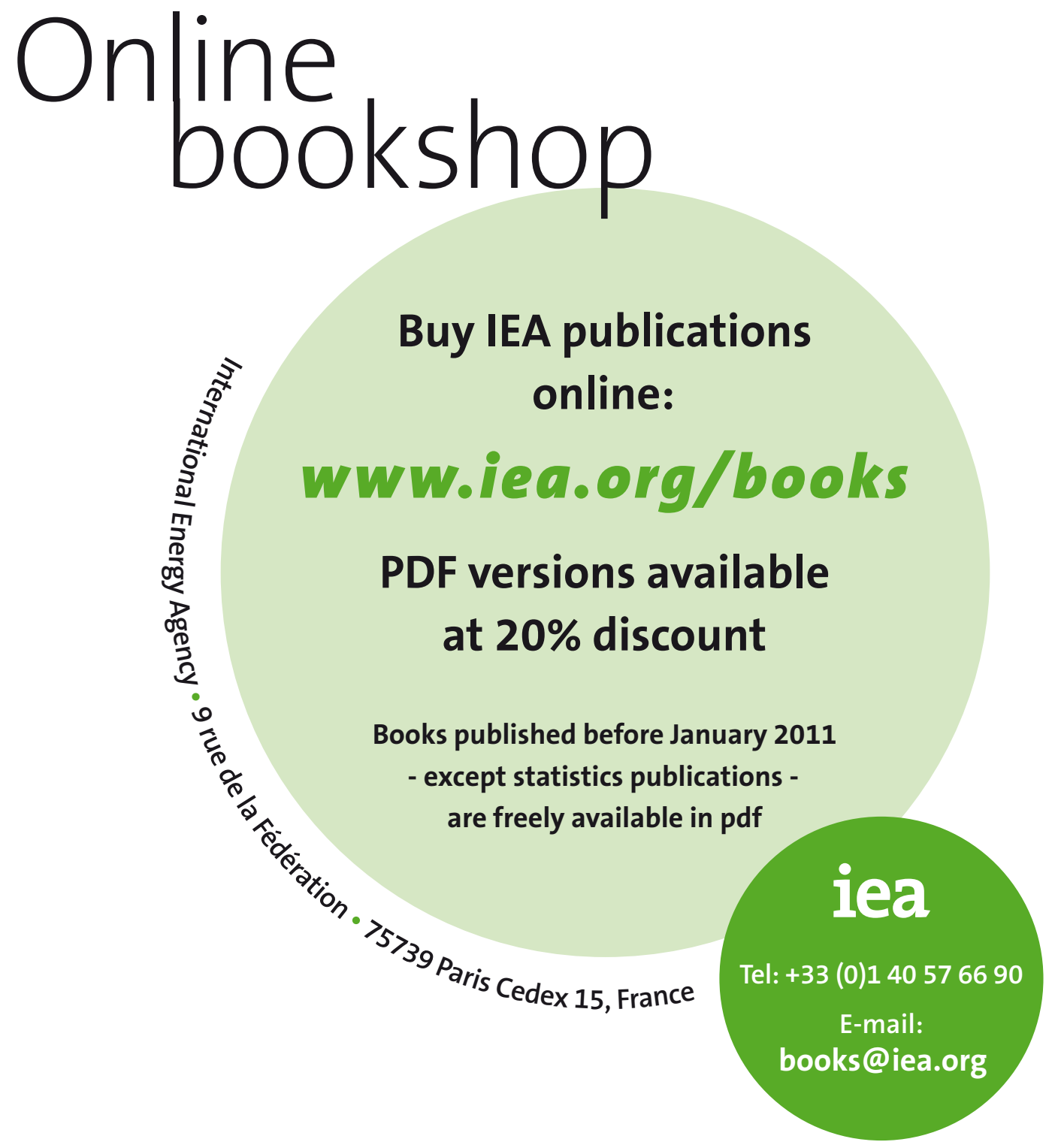